\title{
Forensic investigation of flowslides triggered by the 2018 Sulawesi earthquake
}

\author{
Divyesh Rohit ${ }^{1 *} \mathbb{0}$, Hemanta Hazarika' ${ }^{1}$ Tsubasa Maeda' ${ }^{1}$, Wa Ode Sumartini ${ }^{1}$, Takaji Kokusho², \\ Siavash Manafi Khajeh Pasha ${ }^{3}$ and Sukiman Nurdin ${ }^{4}$
}

\begin{abstract}
The Sulawesi earthquake with a moment magnitude of $M_{w} 7.5$ struck the Central Sulawesi region of the Sulawesi Island, Indonesia, on September 28, 2018. The epicenter of the earthquake was located in the mountainous region of Donggala Regency, in the neck of the Minahasa Peninsula in the Central Sulawesi Province of Indonesia. Although the epicenter was located in Donggala Regency, the greatest devastating effects were observed about $70 \mathrm{~km}$ south of the epicenter in the Palu Valley. The event was the first of its kind to cause large-scale flowslides simultaneously at four key locations such as Balaroa, Petobo, Jono Oge, and Sibalaya with extensive ground displacements ranging from several hundred meters to more than $1 \mathrm{~km}$. This article reviews the field observations of geotechnical failures and infrastructure damage caused by liquefaction resulting from the shallow strike-slip earthquake at Palu City, Donggala Regency, and Sigi Regency. A geo-spatial analysis was performed on data collected from aerial drone imagery, along with portable dynamic cone penetration testing (PDCPT) in the field. The investigation revealed a highly stratified ground with alternating soil layers of varying permeability and very low bearing resistance at shallow depths. The investigation also helped in assessing the extent of damage caused by geotechnical failure to the residential infrastructures, irrigation structures, and roads.
\end{abstract}

Keywords: Capping layer, Forensic investigation, Large-scale flowslides, Sulawesi earthquake, Water film

\section{Introduction}

Located along the Ring of Fire, Indonesia constantly experiences turbulent tectonic activities such as earthquakes, volcanoes, and tsunami. On September 28, 2018, at 10:02:44 AM local time, the region of Central Sulawesi (Sulawesi Tengah) in Sulawesi Island of Indonesia was hit by an earthquake of significant moment magnitude $M_{\mathrm{w}}$ 7.5. The earthquake shook the entire Sulawesi Island as well as some regions of neighboring Borneo Island and parts of Malaysia. The resulting ground rupture and liquefaction caused extensive damage to critical infrastructure such as bridges, roads, irrigation canals, and the built environment in the Palu Valley. The event not only caused damage to infrastructure but also resulted in the

\footnotetext{
*Correspondence: rohit.divyesh@gmail.com

${ }^{1}$ Kyushu University, Nishi-ku, Fukuoka 819-0395, Japan

Full list of author information is available at the end of the article
}

loss of thousands of lives and serious injuries to many more.

The Sulawesi earthquake triggered large-scale landslides and liquefaction at several locations in the Palu Valley, namely Balaroa, Petobo, Jono Oge, Lolu, and Sibalaya (Mason et al. 2019; Hazarika et al. 2021a, b). In all these locations, the landslides occurred rapidly, with ground movement in massive blocks along with debris flow; therefore, these can be classified as flowslides according to the Varnes classification (Hungr et al. 2014). These flowslides occurred in a very gently sloping terrain with a gradient of less than 4\% (Hazarika et al. 2021a, b).

Our research team visited the sites and conducted field investigations: taking high-resolution aerial photographs with a DJI Phantom 4 Pro V2.0 Plus drone, visually inspecting the sites, collecting disturbed and undisturbed soil samples, conducting portable dynamic cone penetration tests in the field to evaluate subsurface soil 
strength, and conducting trench surveys to observe the vertical subsurface soil profile. In this paper, we present the detailed results of our forensic investigation of the flowslide sites along with the surrounding areas and propose a mechanism and factors that may have triggered these flowslides. These findings provide comprehensive insights into the damage caused by the flowslides and are unique in this research. The geomorphic alteration and subsurface geology of the failed sites are also discussed in detail, which is unique to this study.

\subsection{Event attributes}

The epicenter of the Sulawesi earthquake was located at $0^{\circ} 15^{\prime} 21.6^{\prime \prime} \mathrm{S} 119^{\circ} 50^{\prime} 45.6^{\prime \prime} \mathrm{E}$, in the mountainous region of Donggala Regency at a hypocentral depth of about $20 \mathrm{~km}$ (USGS 2018). The region had already experienced a $M_{\mathrm{w}} 6.1$ magnitude earthquake just 3 hours before the mainshock. The Palu Valley experienced a peak intensity of 8.5 on the MMI scale and a peak ground acceleration of $0.5 \mathrm{~g}$ from the mainshock (USGS 2018). The locations of the foreshock, mainshock, and peak ground acceleration (PGA) contour in the region due to the event are shown in Fig. 1. The fault-plane solution of the foreshock and mainshock highlights a shallow strike-slip fault mechanism of the Palu-Koro Fault (PKF) that triggered the earthquake. Earthquake parameters obtained from USGS (2018) and the Global Centroid Moment Tensor project (GCMT) are shown in Table 1.

Interestingly, the earthquake triggered the extensive flowslides about $70 \mathrm{~km}$ from the epicenter, in several locations in the Palu Valley. Areas such as Balaroa, Petobo, Jono Oge, and Sibalaya were the worst affected by the extensive flowslides (Fig. 2). This damage in areas far from the epicenter is believed to result from supershear rupture caused by the earthquake, which brings strong shaking in the far field of the fault plane (Zhang et al. 2017). All the flowslides sites except Balaroa were surrounded by water bodies on at least two sides (Fig. 2). Petobo, Lolu, and Jono Oge had the Gumbasa irrigation canal running along the crest of the sites, while the Palu River, running along the centerline of the Palu Valley, was present on the downstream side. It was reported

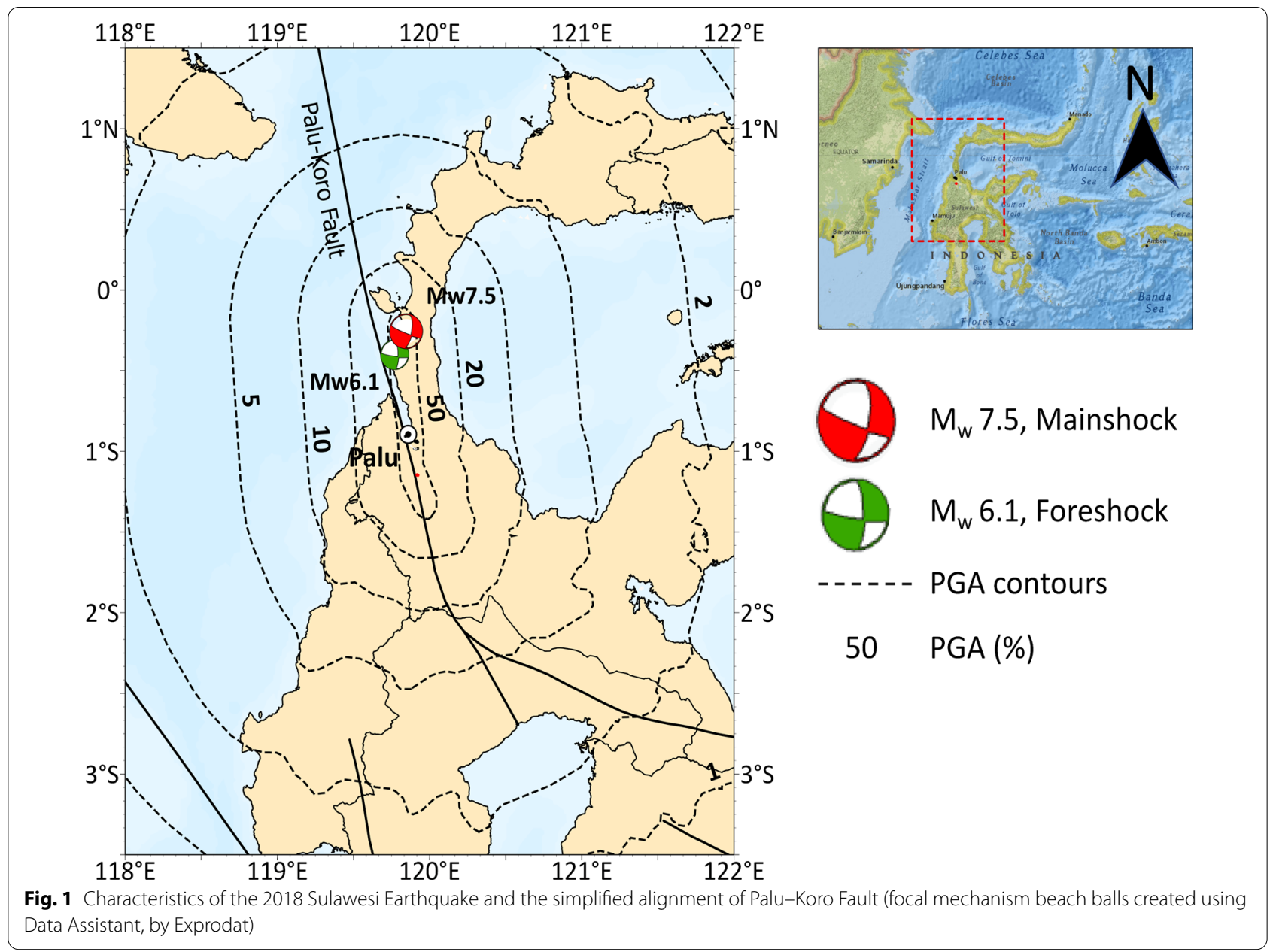


Table 1 Seismic parameters reported by USGS and GCMT for the 2018 Sulawesi earthquake

\begin{tabular}{|c|c|c|c|c|c|c|}
\hline Parameter & & & Global CMT & & & USGS \\
\hline Centroid time & & & 10: 2: 59.4 GMT & & & 10:02:45 UTC \\
\hline Hypocentral depth $(\mathrm{km})$ & & & 12 & & & 20 \\
\hline Half duration (s) & & & 14.2 & & & 20.48 \\
\hline$M_{\mathrm{w}}$ & & & 7.6 & & & 7.53 \\
\hline$M_{s}$ & & & 7.5 & & & - \\
\hline$M_{\mathrm{b}}$ & & & - & & & - \\
\hline \multirow[t]{2}{*}{ Scalar moment (nm) } & & & $2.82 E+27$ & & & $2.497 \mathrm{E}+20$ \\
\hline & Strike & Dip & Slip & Strike & Dip & Slip \\
\hline Fault plane 1 & $87^{\circ}$ & $77^{\circ}$ & $-146^{\circ}$ & $87^{\circ}$ & $74^{\circ}$ & $-156^{\circ}$ \\
\hline Fault plane 2 & $348^{\circ}$ & $57^{\circ}$ & $-15^{\circ}$ & $350^{\circ}$ & $67^{\circ}$ & $-17^{\circ}$ \\
\hline
\end{tabular}

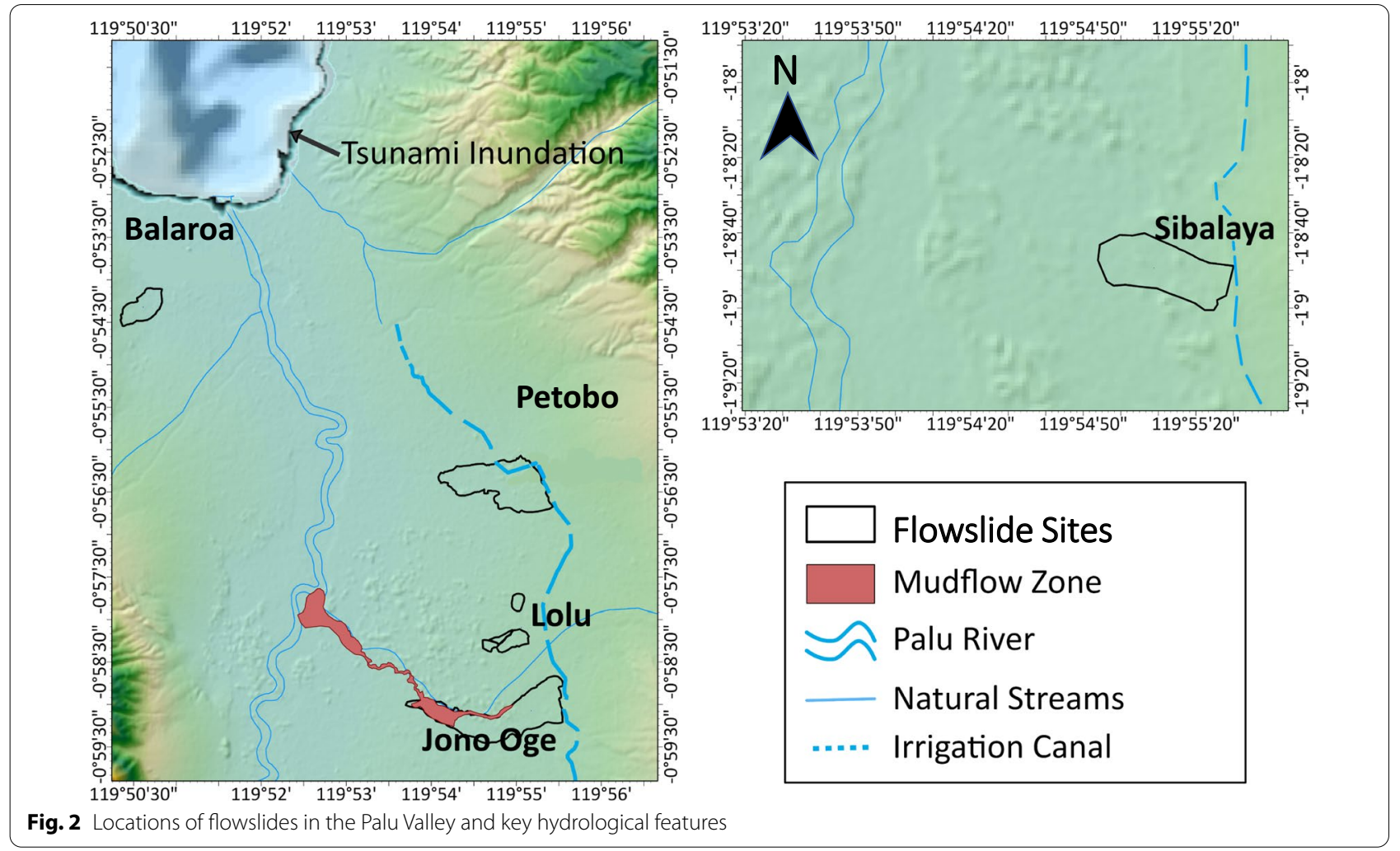

that the irrigation canal was full of water at the time of the earthquake (Gallant et al. 2020). The rupture of the canal caused debris flow along with the flowslide, which increased the damage potential and also acted as the main factor for the flowslides.

\subsection{Infrastructural damage}

The flowslides swept several residential buildings along with the underlying soil mass hundreds of meters to a kilometer away from their original position, destroying them (Hazarika et al. 2021a, b; Kiyota et al. 2020; Okamura et al. 2020). Figure 3a-d shows the extent of damage to housing structures in Balaroa, Petobo, Jono Oge, and Sibalaya, respectively (BNPB ArcGIS REST Service 2020). Damage from liquefaction-induced flowslides was also assessed by creating a Normalized Differential Vegetation Index (NDVI) image from Landsat 8 data (Global Change Master Directory (GCMD) 2020). NDVI is a graphical index that is a measure of green vegetation, with values defined from -1 to 1 in the index, with values 

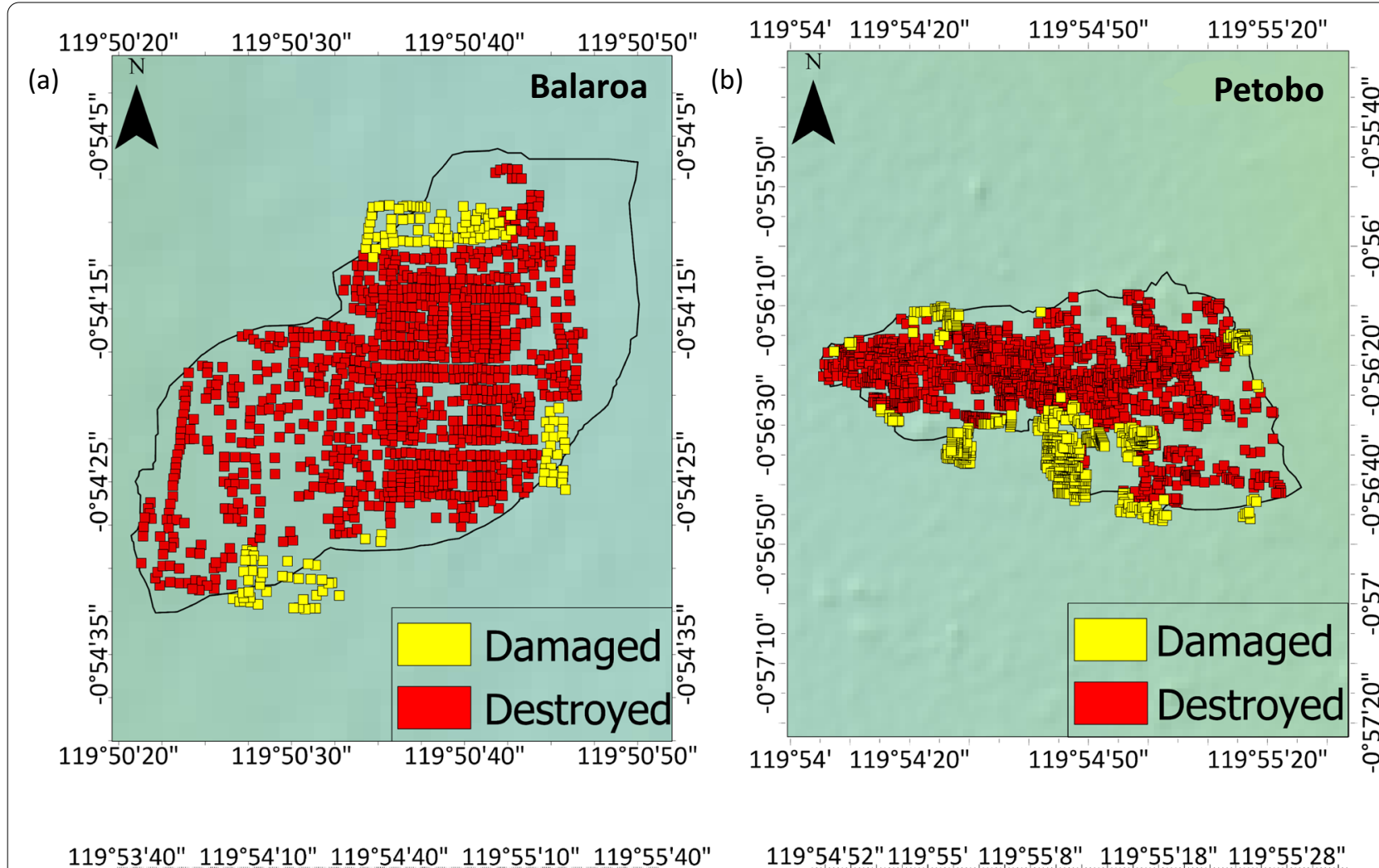

(c)

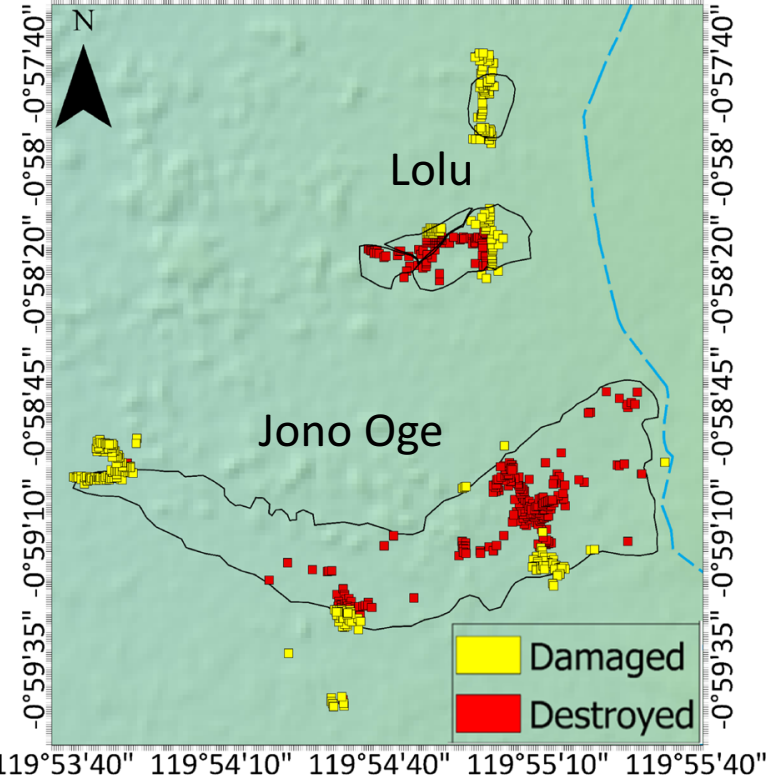

$119^{\circ} 54^{\prime} 52^{\prime \prime} 119^{\circ} 55^{\prime} 119^{\circ} 55^{\prime} 8^{\prime \prime} 119^{\circ} 55^{\prime} 18^{\prime \prime} 119^{\circ} 55^{\prime} 28^{\prime \prime}$

(d)

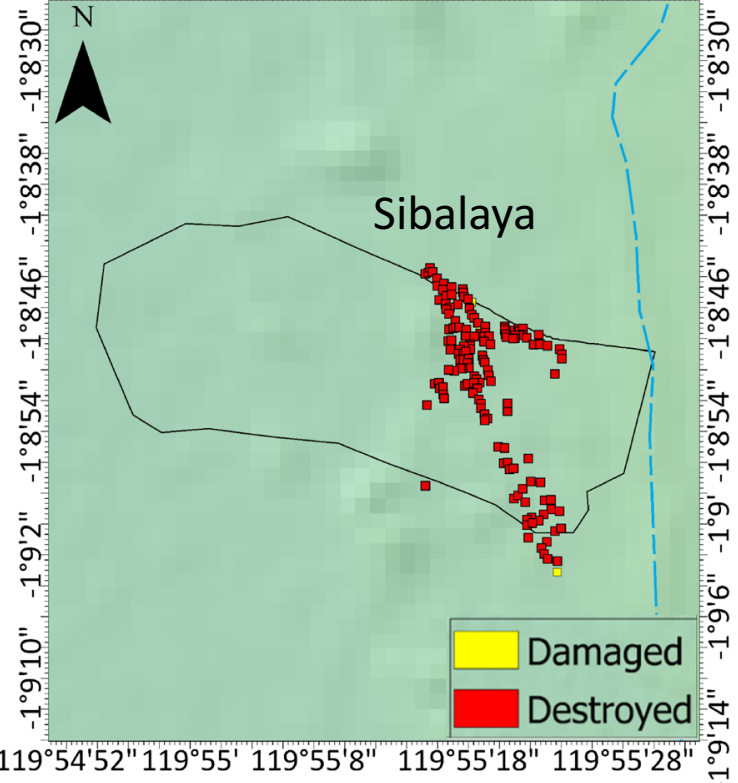

Fig. 3 Extent of damage to housing infrastructure due to flowslides: a Balaroa, b Petobo, c Jono Oge and Lolu, and d Sibalaya (Modified from BNPB ArcGIS Map Service, Copernicus Data Source)

toward a positive 1, defining good plant health and vegetation, and vice versa. The before and after NDVI images for the Palu Valley are shown in Fig. 4. Figure 4 shows two images, one taken on September 23, 2018 (before the earthquake), and the other taken later on October 2, 2018 (after the earthquake). The Petobo, Jono Oge, and Sibalaya sites had a significant area covered with rice paddies and coconut plantations that were destroyed 

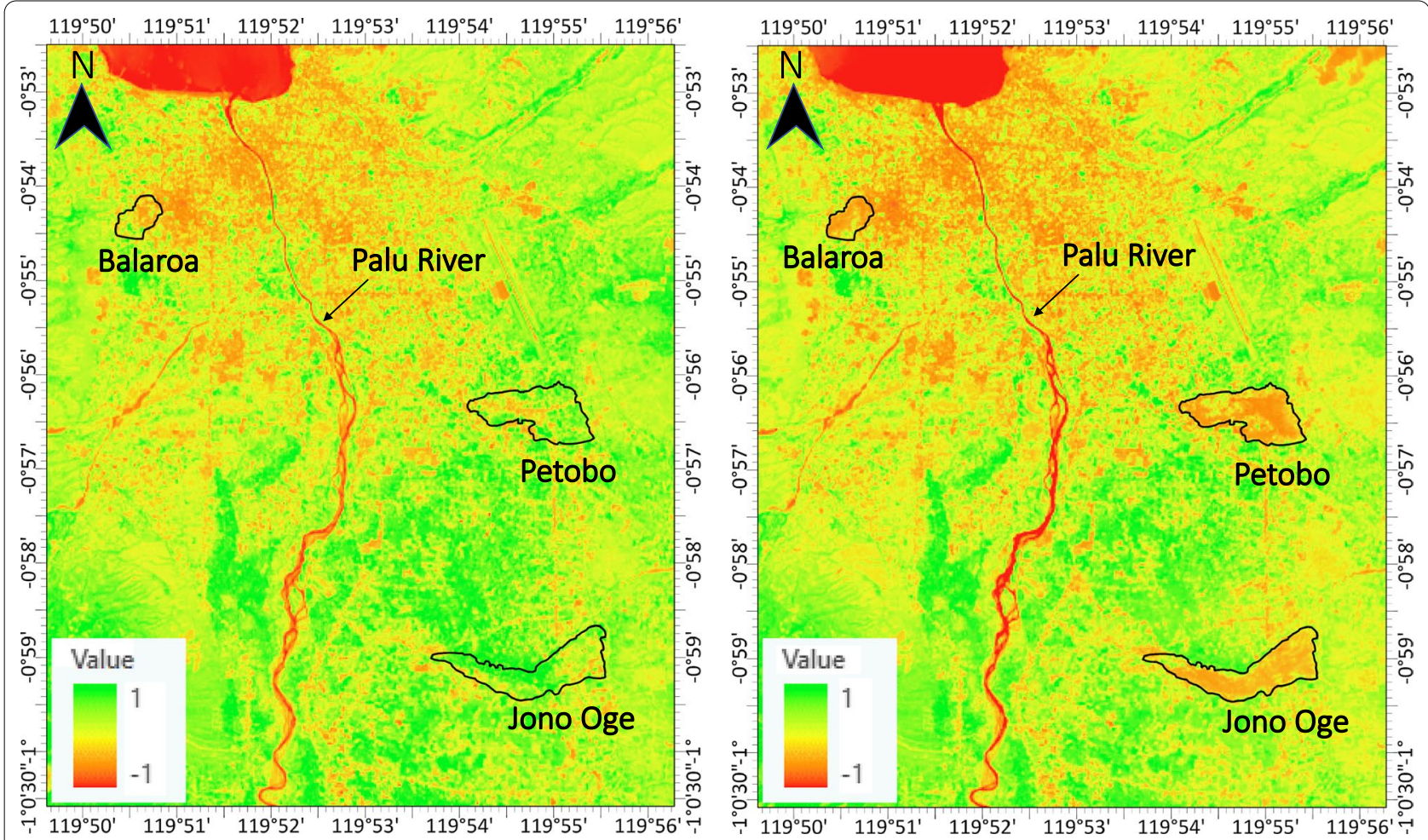

Fig. 4 NDVI graphic representation of the Palu Valley before (September 23, 2018) and after (October 2, 2018) the 2018 Sulawesi earthquake

and displaced by the flowslides. This change in vegetation cover is evident from the contrasting images where before the earthquake these areas show a healthy green cover with NDVI value close to $(+) 1$, while after the earthquake the NDVI of these areas goes toward $(-) 1$.

\subsection{Geodynamics of Palu Valley and seismotectonic of Sulawesi Island}

To understand massive geotechnical failures, it is always advisable to look below the Earth's surface to understand the geology of the area and its formation as well as the seismological history of the region. In this section, the geology of the Palu area and the seismicity of the PKF are discussed in more detail.

\subsubsection{Geology of Palu Valley}

The Valley of Palu was formed by trans-tensional tectonics involving the Palu-Koro Fault (PKF) system. The geologic map of the Palu region showing the locations of the flowslide is depicted in Fig. 5. The bedrock in the Palu region consists predominantly of the Palu Metamorphic Complex (PMC) overlain by Cenozoic sedimentaryvolcanic Upper Cretaceous successions. This complex forms the rugged mountain range on the eastern flank of the valley (van Leeuwen et al. 2016). Neogene sedimentary rocks, informally called Celebes Molasse, are also prevalent in Sulawesi, consisting predominantly of conglomerates, sandstones, and mudstones with limestone interbeds (Surono and Sukarna 1996). To the south, the PMC is surrounded and covered by Upper Cretaceous Latimojong Formation, which comprises mainly weakly metamorphosed pelitic and fine-grained psammitic rocks with subordinate intercalations of volcanic rocks (van Leeuwen and Muhardjo 2005; Simandjuntak and Supandjono 1991). The Malihan rocks or the Malino Metamorphic Complex consists mainly of mica schists, gneisses, greenschist, amphibolite, marble, and quartzite (van Leeuwen et al. 2007). The Gumbassa Complex contains metamorphic rocks equivalent to the PMC.

In addition, the Palu Valley is flanked on both sides by mountains running North-South with peaks up to $2.3 \mathrm{~km}$ high (Bellier et al. 2001). While the highs are dominated by metamorphic complexes and granitic rocks, the middle and lower ranges consist of the old $(\sim 120 \mathrm{Kya})$ and young ( 11 Kya) alluvium deposits on the western and eastern flanks of the Palu Valley along with debris flow deposits (Patria and Putra 2020). The central part of the Palu Valley, which is the floodplain of the Palu River, consists mainly of alluvial deposits, flood deposits, and old river channel deposits (Kusumawardani et al. 2021). The alluvial deposits are mostly distributed as fans of the rivers flowing west and downstream of the Palu River. These 


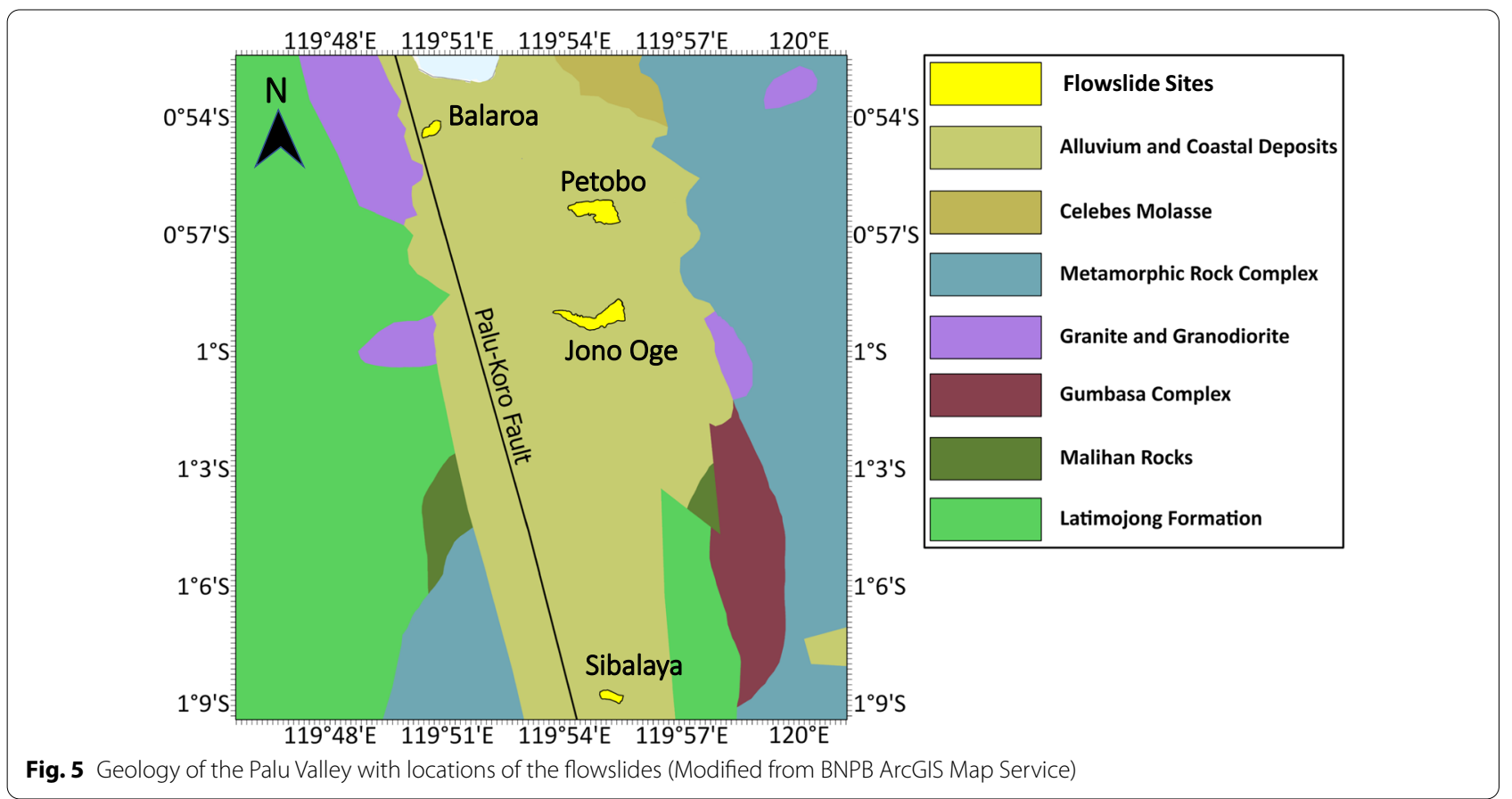

fans are mainly deposited as seams of sand, gravel, and silt (The Surficial Minerals Exploration Agency 1973).

\subsubsection{Tectonics of Sulawesi Island}

The location of Sulawesi Island is one of the main reasons for the consistent seismic events it experiences, as it lies at the tri-junction of the Australian, Eurasian, and Philippine Sea plates (Hamilton 1979) with a complex memoir of subduction, extension, ophiolite obduction, and collision of continental fragments (Hamilton 1979; Hall 2014). There are several active major and minor faults in Sulawesi that have been responsible for historical earthquakes of magnitude $\geq 6$. The Central Sulawesi region, the most seismically active part of Sulawesi, was formed by multistage subduction and collision of the tectonic plates (Bellier et al. 2006). Figure 6 shows the active faults in Central Sulawesi and the fault mechanisms of some major historical earthquakes $(M \geq 6)$ that occurred in the region (fault locations after BNPB (2020); focal mechanism beach spheres created with Data Assistant, by Exprodat).

Sulawesi hosts one of the most active strike-slip faults in the world, the Palu-Koro Fault (PKF), which divides the Central Sulawesi Province into two parts, the western Central Sulawesi, which forms the northern part of the Makassar block, and the seismically active Eastern Central Sulawesi (ECS) (Fang et al. 2019). The PKF is considered an active zone with significant strain with an estimated annual sinistral slip rate of $39 \mathrm{~mm}$ and extension rate of $11 \mathrm{~mm}$ (Socquet et al. 2006). In addition, previous research (Watkinson and Hall 2017) has claimed that the PKF is capable of generating supershear earthquakes such as the 2018 Sulawesi earthquake, with its shallow seismicity. Supershear ruptures tend to generate an S-wave stem that can travel long distances, and the seismic energy they transmit has high amplitudes that amplify the damage as observed in Palu. The Sulawesi region also hosts several smaller faults such as the Bada Valley fault, the Matano fault, the Sausu fault, and the Takararu fault, which are shown in Fig. 6 but outside the scope of this study.

\section{Results and discussion}

This section describes the damage caused by the liquefaction-induced flowslides to the built environment at Balaroa, Petobo, Jono Oge, and Sibalaya. A remote sensing survey was conducted using a drone for an overall assessment of the sites. The soil profile of the failed areas was thoroughly examined using the trenches excavated on site, and soil samples were collected from various elevations in the trenches. In addition, portable dynamic cone penetration tests (PDCPT) were conducted at some locations to assess the in situ soil strength and compared to the actual soil profile. The $N$ values $\left(N_{\mathrm{d}}\right)$ obtained from the PDCPTs were then converted to standard penetration test $\left(N_{\mathrm{SPT}}\right)$ values using the empirical equations available in Takase and Sasada (2013). PDCPT was preferred over other in situ sounding tests because it is convenient to transport to any location, rapid results, and low manpower requirements. The instrument has an effective 


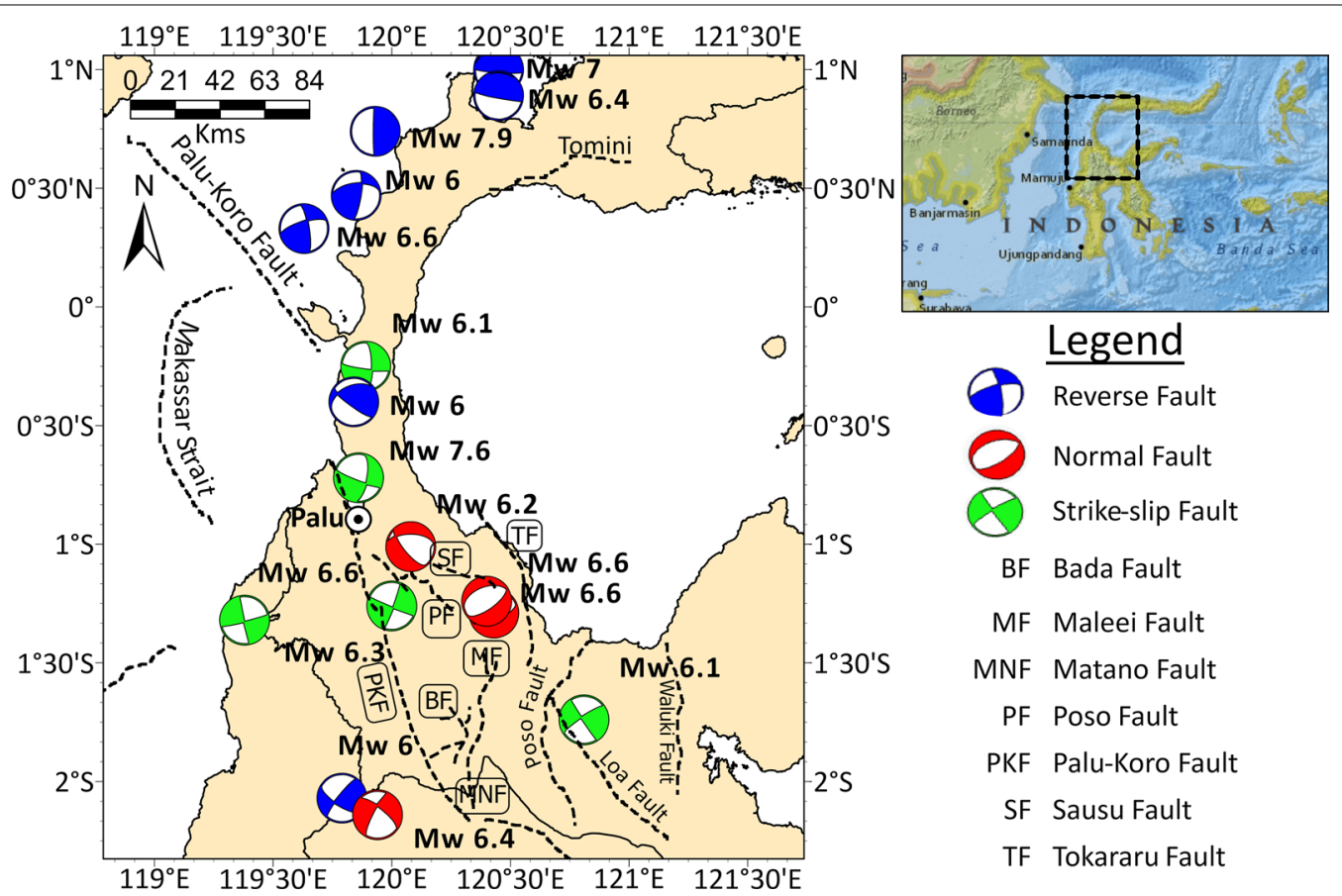

Fig. 6 Focal mechanism of past earthquakes $(M>6)$ in Central Sulawesi and the locations of some of the active faults

range of $5 \mathrm{~m}$ and is not suitable for hard clays and sands or sand and gravel foundations with high penetration resistance. The tests were conducted in accordance with JGS 1433-2012.

\subsection{Balaroa}

The Balaroa flowslide site is located on the seaside of the valley of Palu. It had a dense urban environment, making the damage to human life much higher compared to Petobo, Jono Oge, and Sibalaya, which covered larger area. In addition, there was no canal structure aligned near this site. The Balaroa flowslide engulfed an area of $0.4 \mathrm{~km}^{2}$ with the destruction of more than 1300 structural units. The Balaroa site also had a very gentle gradient of less than 5\% prior to the flowslide (Kiyota et al. 2020), but was comparatively steeper than other sites. Our team was only able to conduct a limited reconnaissance of this site due to access issues and time constraints. Figure $7 \mathrm{a}, \mathrm{b}$ shows the before and after images of the Balaroa site. The site can be divided into two zones: the tension zone and the compression zone. The flowslide started in the tension zone with the ground moving in large blocks with the overlying residential houses, which then piled up in the compression zone. A 3D image generated from analysis of drone survey data using Agisoft PhotoScan Professional software is shown in Fig. 8a. The extent of vertical ground displacement is shown in Fig. $8 \mathrm{~b}$, in which the height of the vertical ground profile near the crown appears to be about three times the normal ground structures present at the edge from visual observation. The vertical reduction in ground elevation appeared to be about three times $(3 N)$ the elevation of the house $(N)$. In addition, the site had a very shallow water table that was nearly at the surface as observed by the authors during the survey. This could be confirmed by the presence of natural groundwater gushing out from the rubble (Fig. 8c). It also confirms the theory of the presence of an artisan aquifer by Kiyota et al. (2020).

\subsection{Petobo}

The Petobo site is located near the Palu airport and had a semi-urban setting with houses and rice fields, while hydrologic characteristics are similar to Jono Oge and Sibalaya. The Petobo flowslide devoured an area of about $1.81 \mathrm{~km}^{2}$ and destroyed more than 1900 residential buildings. The area was more densely populated compared to Jono Oge and Sibalaya and had a gentle ground profile of less than $3 \%$. The topsoil of the Petobo site consists of an old alluvium fan deposit in the upstream part, while the downstream part consists of alluvial deposit, flood deposit, and the old river channel deposit which can also be classified as a fluvial deposit (Kusumawardani et al. 2021). Here, in Fig. 9a, b, the satellite images of the site at different time points are shown to illustrate the change in geomorphology and soil characteristics. Again, there are two sections of the flowslide, with the upstream section 
(a)

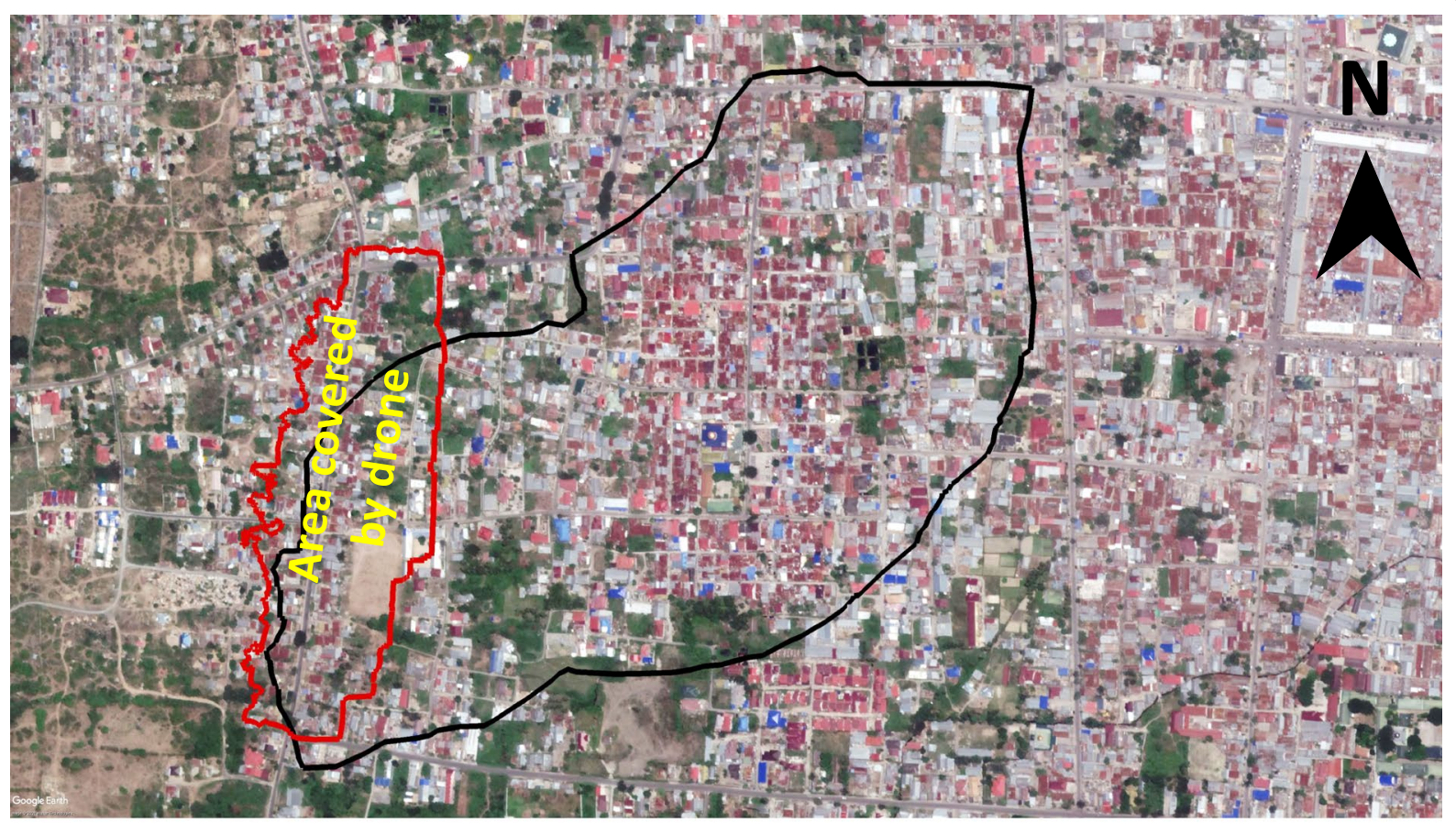

(b)

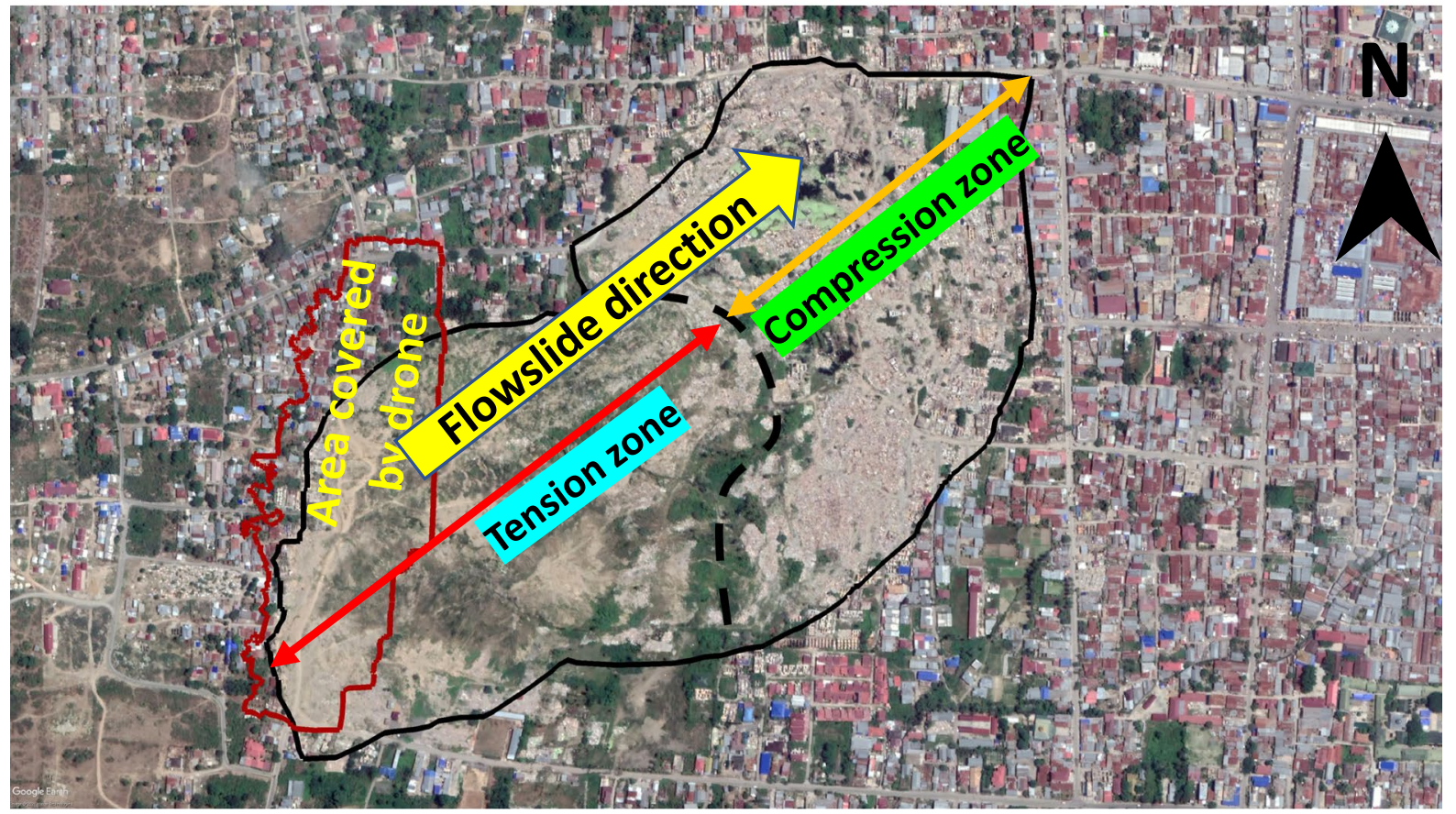

Fig. 7 Aerial view of Balaroa flowslide site: a before (March 11, 2018) and b after (March 21, 2019) the earthquake (Modified from Google Earth)

experiencing an abrupt ground displacement in both horizontal and vertical directions, while the downstream section experiencing an increase in elevation due to the accumulation of debris from the upstream section. Figure 10a shows the aerial view of the site, which illustrates the extent of the tensile cracks near the head scarp. It also indicates incremental slumping of the ground surface in large blocks. The extent of vertical height loss is shown in Fig. 10b where the rice field is partially intact, while a large portion has slid. It has been reported that the elevation drop near the crown of the site is about $5-8 \mathrm{~m}$, while the elevation in the compression zone has increased by 


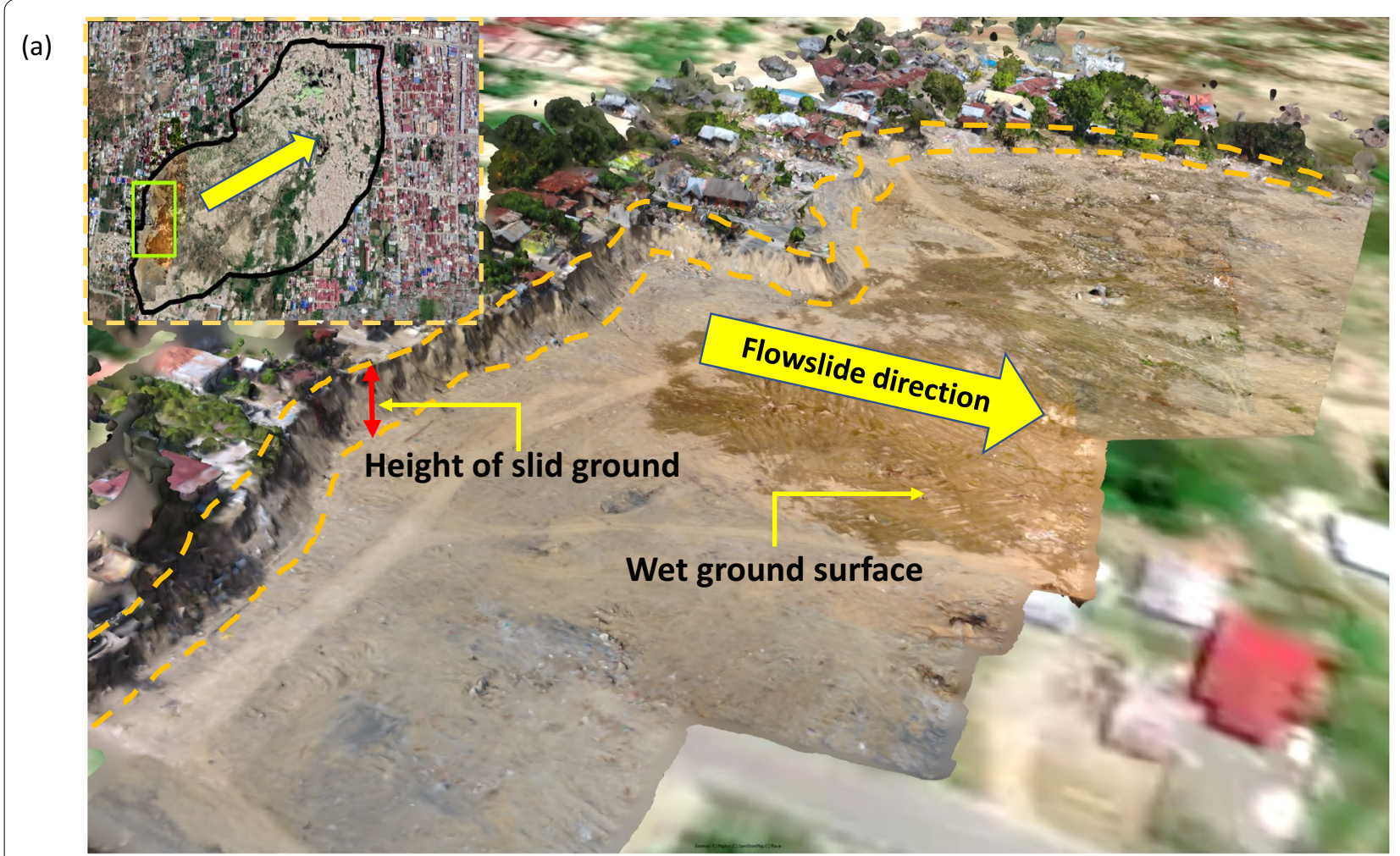

(b)

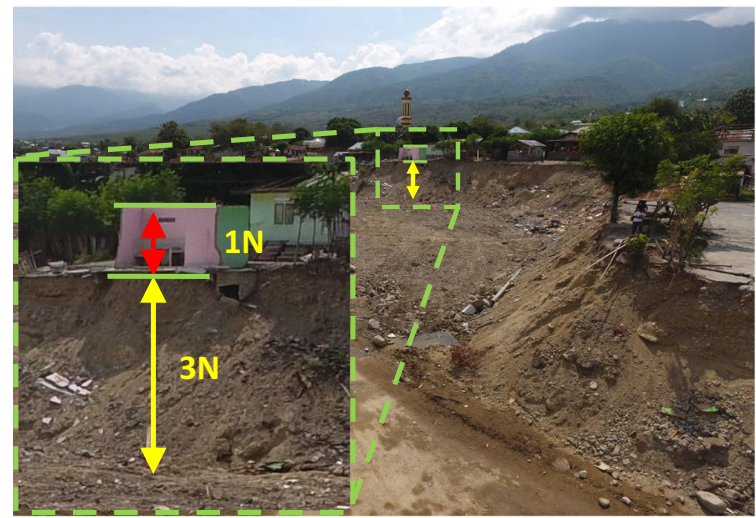

(c)

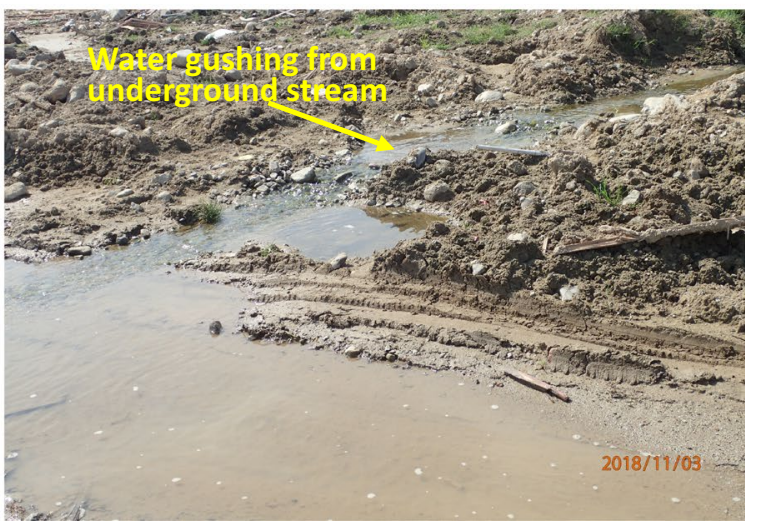

Fig. 8 Site investigation results from Balaroa: a 3D model generated with drone survey. $\mathbf{b}$ Extent of vertical ground displacement and $\mathbf{c}$ water gushing from underground stream (Survey done on November 3, 2018)

4-10 $\mathrm{m}$ due to the accumulation of debris and bulge caused by the forward thrust of the slide. In addition, the presence of an artisan aquifer and post-slide ponds of water are also reported at the Petobo site (Kusumawardani et al. 2021).

\subsection{Jono Oge}

The village Jono Oge is considered the most damaged in terms of observed ground movements. About $2.1 \mathrm{~km}^{2}$ of the residential and agricultural area is destroyed by the flowslide and mudflow originating from the breached canal (BNPB 2018). The surface geology of Jono Oge is similar to Petobo with some old alluvium fan deposits upstream, alluvial deposits, flood deposits, and old river channel deposits downstream (Kusumawardani et al. 2021; Mason et al. 2019). The flowslide occurred on a very gentle gradient of less than $4 \%$ (Hazarika et al. 2021a, b). Our team conducted an aerial reconnaissance using a drone to assess the damage and obtain a comprehensive overview of the site. Although the survey could 
(a)

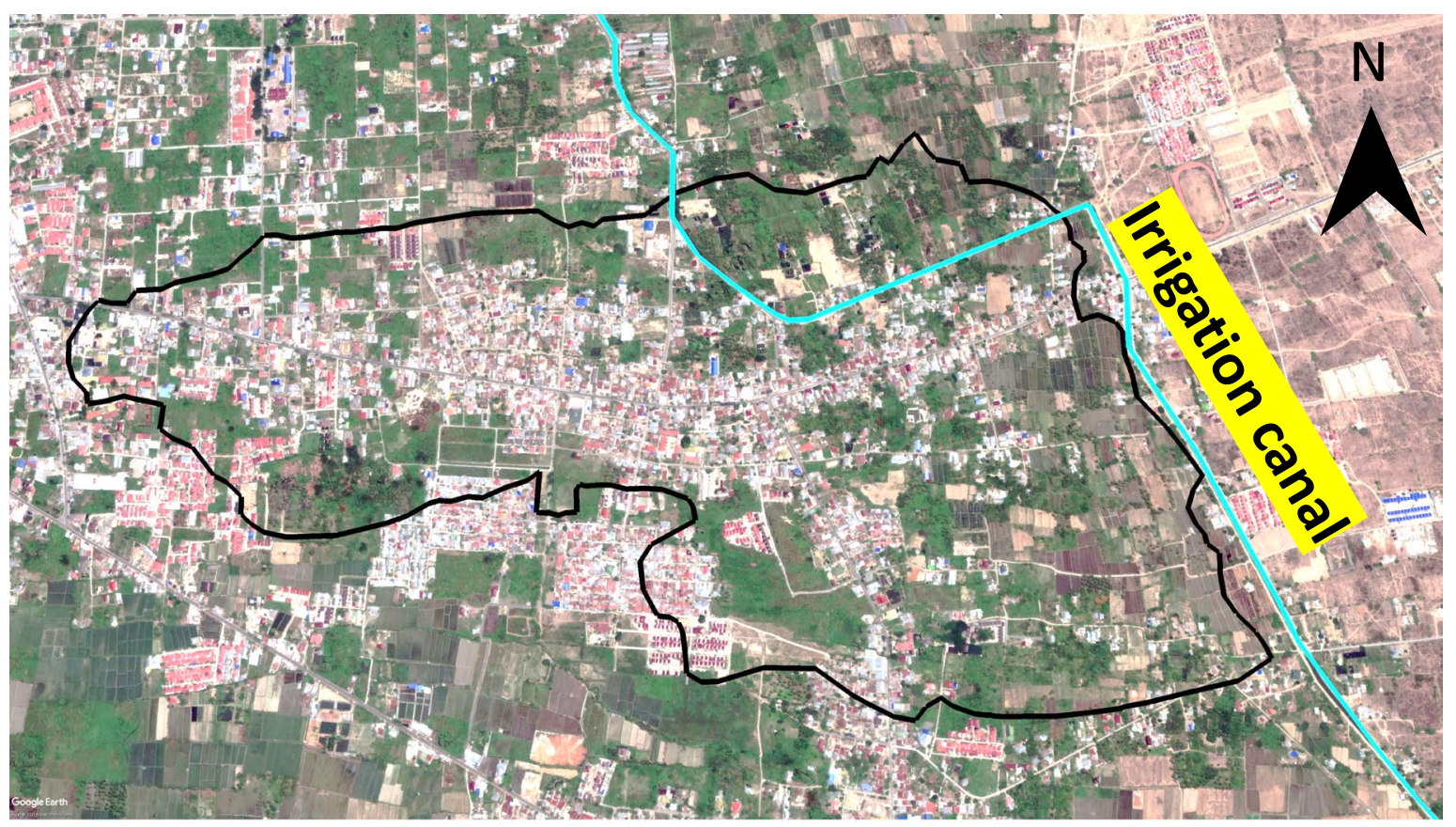

(b)

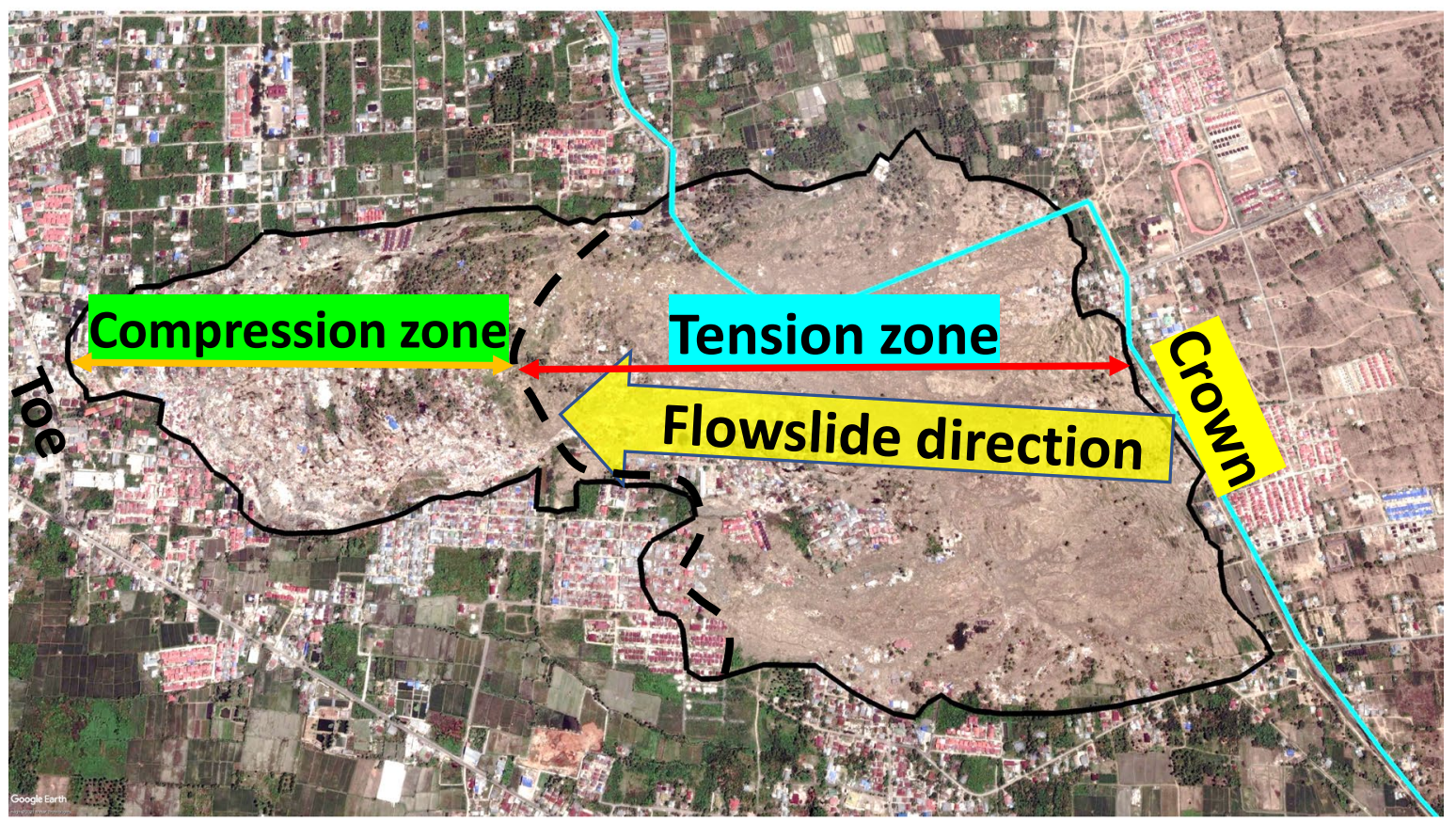

Fig. 9 Petobo flowslide site: a Before (March 3, 2018) and b after (October 2, 2018) the earthquake (Modified from Google Earth)

not cover the entire area of the site, it was helpful in identifying many important features of the flowslide as well as the destruction it caused. An orthomosaic image was created from the drone images collected during the aerial survey as shown in Fig. 11. The tensile cracks appear from the crest of the flowslide, which then decrease toward the center of the flowslide zone in the southwest direction. It is important to note the rupture of the canal near the crest of the slide, which shows signs of soil erosion due to the flow of water from the canal during the earthquake. This rupture exacerbated the damage from the slide by creating a mudflow in a large portion of the site. In addition, the stream flowing along the right bank of the slide also appears to have ruptured, depositing a 
(a)

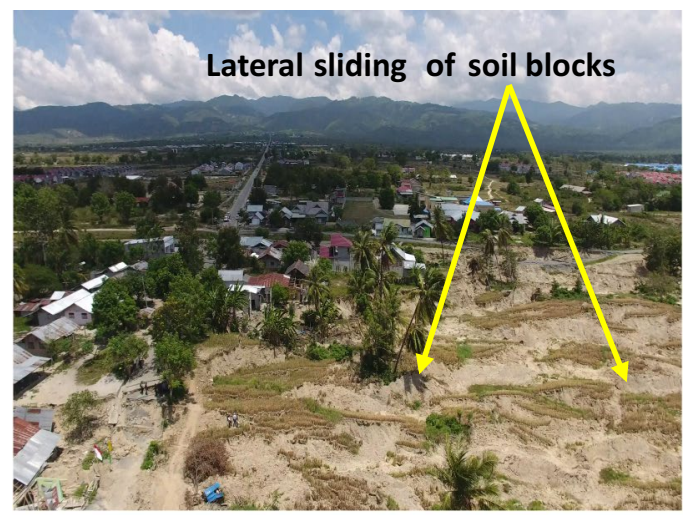

(b)

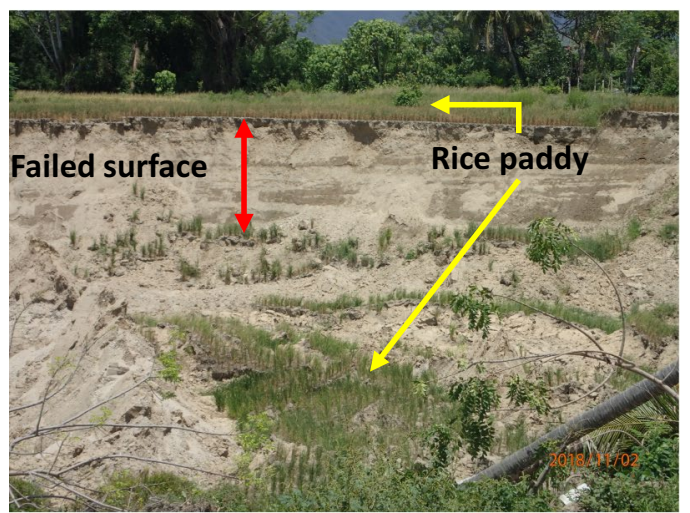

Fig. 10 Images from Petobo flowslide site: a aerial view of the crown area showing tensile cracks, $\mathbf{b}$ vertical soil profile of location near crown (survey done on November 2, 2018)

lot of sediment debris outside its usual flow channel. This rupture is larger than the canal breach and appears to be the most obvious cause of the failure of the bridge connecting the site by scouring its abutment foundation. The extent of vertical ground displacement at the crown of the flowslide is shown in Fig. 12a, which also shows the vertical soil profile at this location. The location of this profile is marked in Fig. 11. Here, superimposed layers of gravelly sand (highly permeable) with sandy silt layers (low permeability) can be seen. The profile also shows the location of disturbed soil samples (J1-J3) collected from the soil wall. The soil gradation curves of the collected samples are shown in Fig. 12b, while Table 2 provides the information on the fines content in the samples. From the gradation curves, it could be clearly inferred that the soil is in the range of highly liquefiable to potentially liquefiable according to the classification of PHRI (1997). As shown in Table 2, samples J1 and J2 have higher fines content and therefore classified as sandy silt, while sample J3 has lower fines content with the presence of coarser soil particles with a higher weight fraction. The soil layers with higher fines content act as a capping layer that prevents the dissipation of the excess pore water pressure that develops in the coarse sand layer, thus forming a low shear resistance meta-stable structure that can fail under a small moment of force or under gravity.

In addition, the geomorphological change of the terrain was evaluated using the pre-earthquake and postearthquake terrain elevation profile (Fig. 13a, b). The pre-earthquake elevation profile (Fig. 13a) was obtained from the freely available DEMNAS data source from the Geospatial Information Agency of Indonesia (BIG 2018), while the post-earthquake elevation data were obtained from the digital elevation model (DEM) generated from the drone image analysis performed. In Fig. 13a, the profile shows a gentle slope with a continuous decreasing elevation profile, while in Fig. 13b, a sump can be seen in the tension zone from where the ground sliding occurred, while on the downstream side, an increase in elevation is seen due to the accumulation of debris and soil blocks along with the hump of the ground due to the forward thrust from the slide.

The earthquake also damaged and destroyed the road and bridge infrastructure in the region, which are important for rapid evacuation and medical care in any disaster. Many bridges and culverts in the area sustained mild to severe damage. Figure 14a shows one such culvert with a displaced deck. Road infrastructure outside and far from the site of the flowslide also got damaged in many locations in Jono Oge village (Fig. 14b). A typical wave effect damage can be seen on the deformed flexible road surface.

\subsection{Sibalaya}

The Sibalaya site is located far from the other three sites of the flowslide and was sparsely populated. Most of the residential structures that were destroyed were located near the main road that runs through the village. The flowslide covered an area of about $0.529 \mathrm{~km}^{2}$ and destroyed about 125 residential units. Similar to Jono Oge, this site is also located on a relatively flat ground with slopes ranging from 2 to 6\% (Gallant et al. 2020). Our team conducted an aerial survey of the site and PDCPTs, as well as disturbed and undisturbed soil sampling from the excavated trenches at the site during our investigation in June-July 2019. Soil profile observations from the trenches, PDCPT results, and soil classification from disturbed samples are discussed here.

An orthomosaic image of the site was created from the drone survey to identify key geological features, change in terrain, and characteristics of the flowslide (Fig. 15). Here, excessive scour and erosion can be seen near the head scarp, which was not seen at Jono Oge where there was complete displacement of the soil in large soil blocks. Scouring had occurred from both flanks, and the middle portion of the head scarp appeared to be partially 


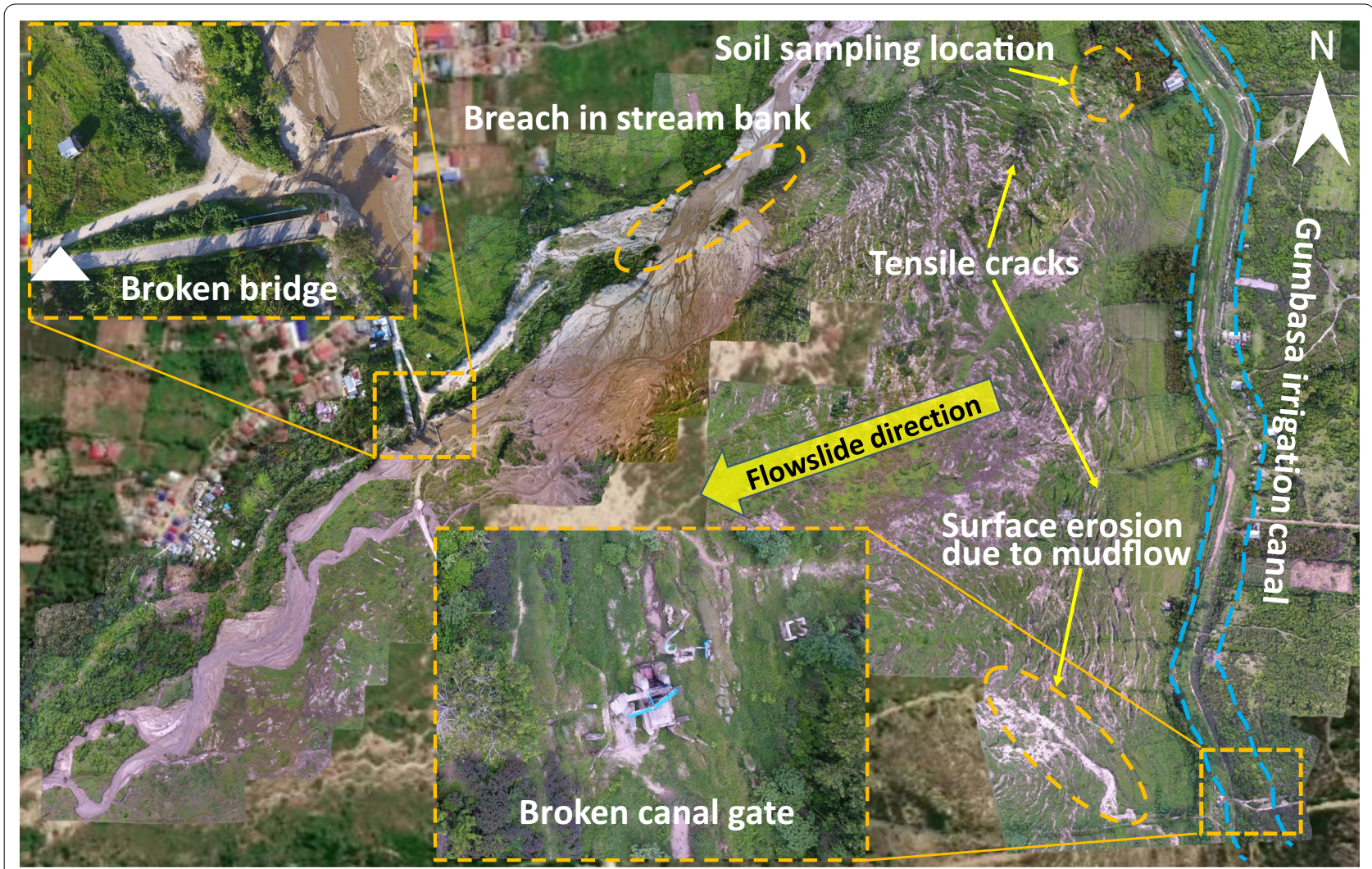

Fig. 11 Orthomosaic image of the Jono Oge site with key observations (surveyed during November 2, 2018)

intact; this suggests a slightly different mechanism of the flowslide compared to the other sites. Most of the houses located near the road were destroyed by the flowslide and washed away with the mudflow caused by the canal rupture, which discharged a tremendous amount of water toward the residential areas. In addition, a large part of the road was displaced by about $300 \mathrm{~m}$ toward the downstream side, as can be seen in Fig. 15. Again, the tensile cracks can be seen on both sides of the displaced road.

The change in the elevation profile of the Sibalaya site was evaluated by generating the raster images from the contour data of the pre- and post-earthquake conditions in a similar manner to Jono Oge. The raster image showing the elevation profile before the earthquake is shown in Fig. 16a (BIG 2018), while Fig. 16b shows the terrain after the earthquake. As can be seen in Fig. 16b, the scouring due to the canal rupture can be seen due to the low elevation of the site. While the elevation contours of the site were smoother before the earthquake, the postearthquake contours show an uneven surface due to the undulation caused by the decrease in elevation and the uplift of the site caused by the flowslide. The intact rock walls behind Trenches 4 and 5 (Fig. 15) can also be seen from the elevation profile.
A visual inspection of the excavated trenches on the site was also carried out to assess the lithology of the subsoil. The detailed soil stratification of the site at various locations and in the direction of flow is discussed below.

\subsection{Trench 1}

Trench 1 is excavated on the left side of the road running through the Sibalaya site (Fig. 15). An image of the soil lithology from the right wall of the trench is shown in Fig. 17a. The trench is excavated at an angle, with the deeper side facing the upstream direction of the flowslide, and the deepest part of the trench was more than $3.6 \mathrm{~m}$ high. The soil profile here appears highly stratified with layers of coarse (gravelly sand) and fine (sandy silt) soil. The right wall is divided into two images as shown in Fig. 17a. The left image, located in the deeper section of the trench, shows no such stratification, while the right image shows significant stratification. Also, it is important to note that the sand is ejected toward the surface, most likely after the flowslide has occurred and the overlying soil has been displaced. In addition, a converging soil boundary is observed with a gravelly sand layer pushing under the clayey sand layer. This could be due to forward thrusting by the slide, which may have caused 


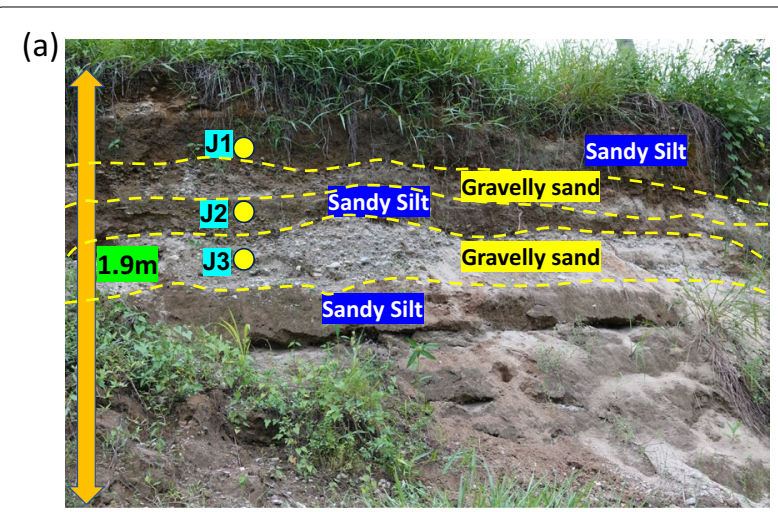

(b)

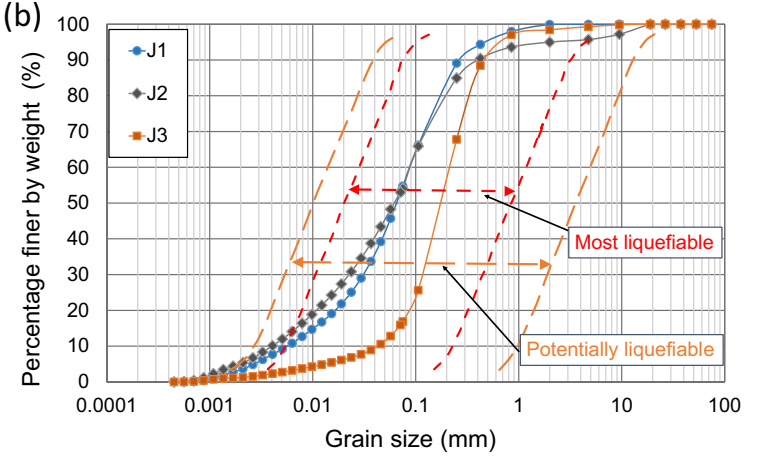

Fig. 12 Soil cliff at the crown of the Jono Oge flowslide site: a vertical soil profile and sampling locations for disturbed soil samples J1-J3 (Image taken June 1,2019) and $\mathbf{b}$ soil gradation curve of samples J1-J3

Table 2 Fines content for samples J1-J3 from Jono Oge crown

\begin{tabular}{lccc}
\hline & J1 & J2 & J3 \\
\hline Gravel $(>2 \mathrm{~mm})$ & 0.1 & 5.0 & 1.6 \\
Sand $(2 \mathrm{~mm}-75 \mu \mathrm{m})$ & 45.2 & 41.7 & 82.4 \\
Silt $(75 \mu \mathrm{m}-5 \mu \mathrm{m})$ & 45.6 & 42.0 & 14.1 \\
Clay $(<5 \mu \mathrm{m})$ & 9.2 & 12.0 & 2.7 \\
$C_{\mathrm{u}}$ & 16.36 & 15.00 & 5.50 \\
$C_{\mathrm{c}}$ & 1.82 & 2.11 & 1.38 \\
Fines content $(\%)$ & 54.7 & 54.0 & 16.9 \\
\hline
\end{tabular}

the clayey soil to attempt to bend the stratified soil layers seen in the right image. The left wall also has similar soil stratification, while the front wall appeared to consist mainly of a sandy layer. Figure $17 \mathrm{a}$ also shows the sampling locations of the disturbed soil samples (S1-S5). The grain size distribution curves of these samples are shown in Fig. 17b, and the fines content of the samples is given in Table 3. Here, samples S3 and S5, which look sticky from the surface, have higher fines content and are in the range of most liquefiable soil type, while sample S1 is partially in the range of most liquefiable to potentially

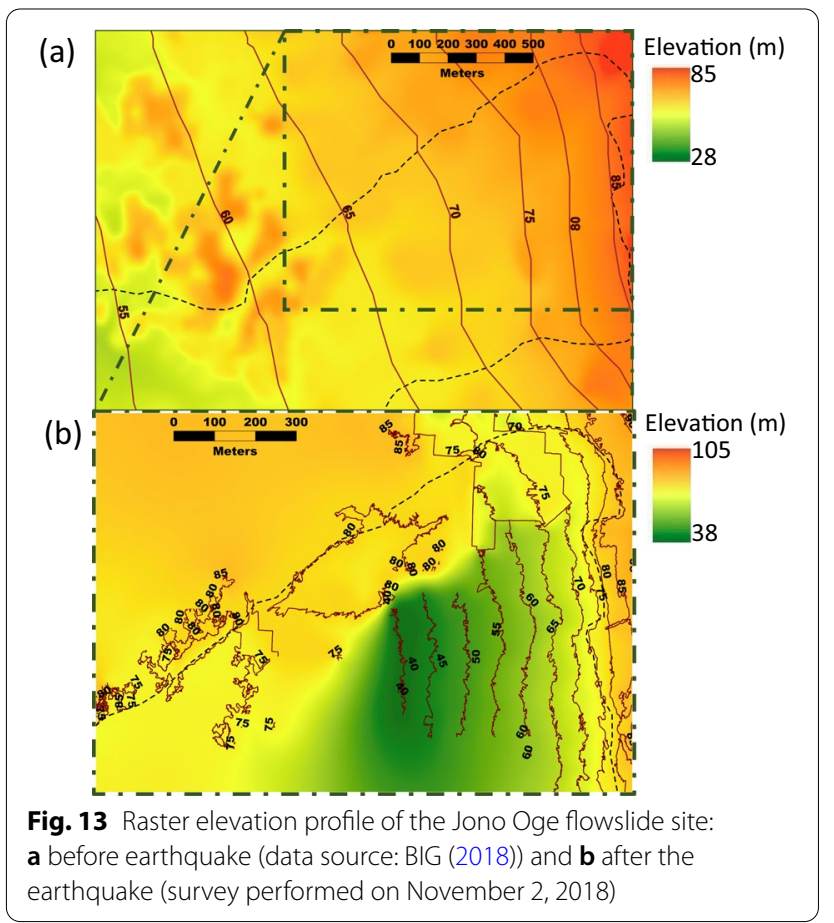

liquefiable, and samples S2 and S4 are in the category of potentially liquefiable soil type. The soil gradation is consistent with the visual observation in the field.

\subsection{Trench 2}

Trench 2 is located close to Trench 1 and has similar alignment. The soil profile of the left wall of the trench is shown in Fig. 18. This trench also has identical soil stratification as Trench 1, although the synclinal alignment of the shallower soil layers is unique, which is not observed in Trench 1 . This feature may have resulted from the forward thrust of the soil blocks moving toward the downstream section during the flowslide and the resistance of the soil layers in the compression zone.

\subsection{Trench 3}

Trench 3 is located in the central section of the flowslide with the deeper side toward the upstream of the flowslide. Figure 19a shows the soil profile of the left wall of Trench 3 , with a much thicker overlying sandy silt layer. The uppermost layer consists primarily of soil transported from the upstream areas of the flowslide, with some remnants of plant roots and plastic bags also trapped in the soil. The surface of the soil layers in this profile is very soft and moist. This is confirmed by the PDCPT 1 conducted adjacent to this trench and shown in Fig. 19b. The PDCPT 1 values were in the range of 5 for sandy silt, silty clay, and clay layers; these soil layers could be classified as very loose soil (USACE 1994). Moreover, these $N$ values 
(a)

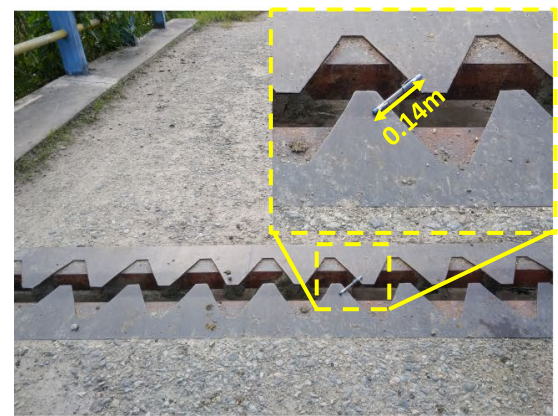

(b)

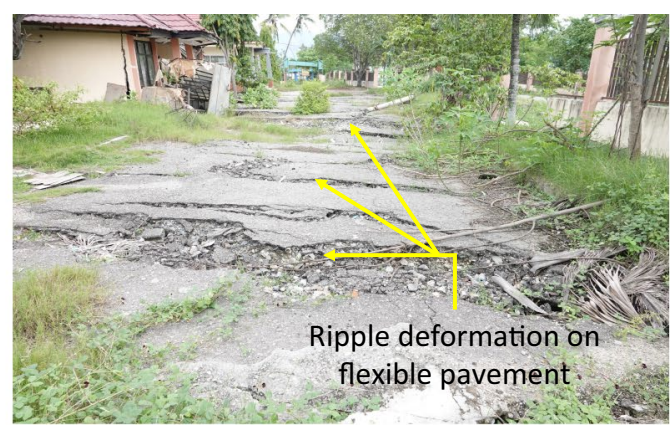

Fig. 14 Damage to infrastructure in Jono Oge village: a displaced culvert deck due to earthquake and $\mathbf{b}$ ripple deformation roads (images taken on July 1, 2019)

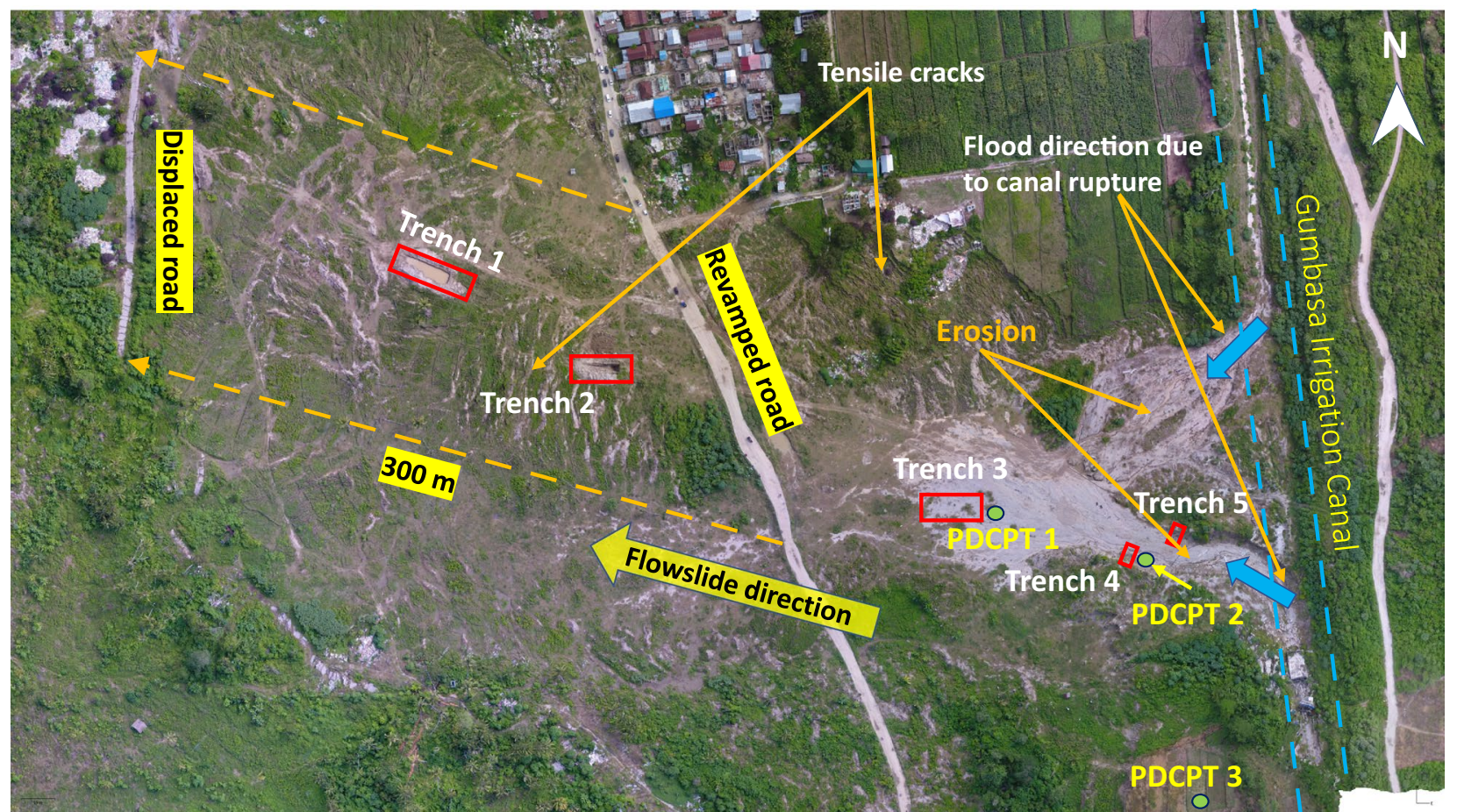

Fig. 15 Orthomosaic image of Sibalaya flowslide site with identification of key features and trench locations (Surveyed on July 1, 2019)

are consistent with the critical $N_{\text {cr }}$ values for soils classified as potentially liquefiable at this depth range (Koizumi 1966). In addition, the $N$ value increased up to 15 for the gravelly sand layer, which then decreases again for the clay layer and then increases at greater depths below the clay layer, confirming a hard stratum at the bottom.

\subsubsection{Trenches 4 and 5}

Trenches 4 and 5 are excavated closer to the crown of the flowslide. The trenches are excavated with length perpendicular to the direction of soil flow. Here, Fig. 20a shows the vertical soil profile of opposite wall of Trench
4, while Fig. 20b shows the $\mathrm{N}$ value versus depth profile of PDCPT 2, conducted adjacent to the trench. Here, the surface soil consists mainly of gravelly sand with small pebbles and rocks as shown in Fig. 20a, while the underlying layers consist of coarse and fine soil layers stacked over each other alternatingly. The PDCPT 2, conducted adjacent to Trench 4, confirms the presence of very loose up to $1.5 \mathrm{~m}$, after which it suddenly gains strength, and no further penetration is observed after 40 blows. This may be due to the presence of dense gravel, as also indicated by the profile of the sandy gravel layer at this depth. Furthermore, PDCPT 3 was conducted in the un-failed area 


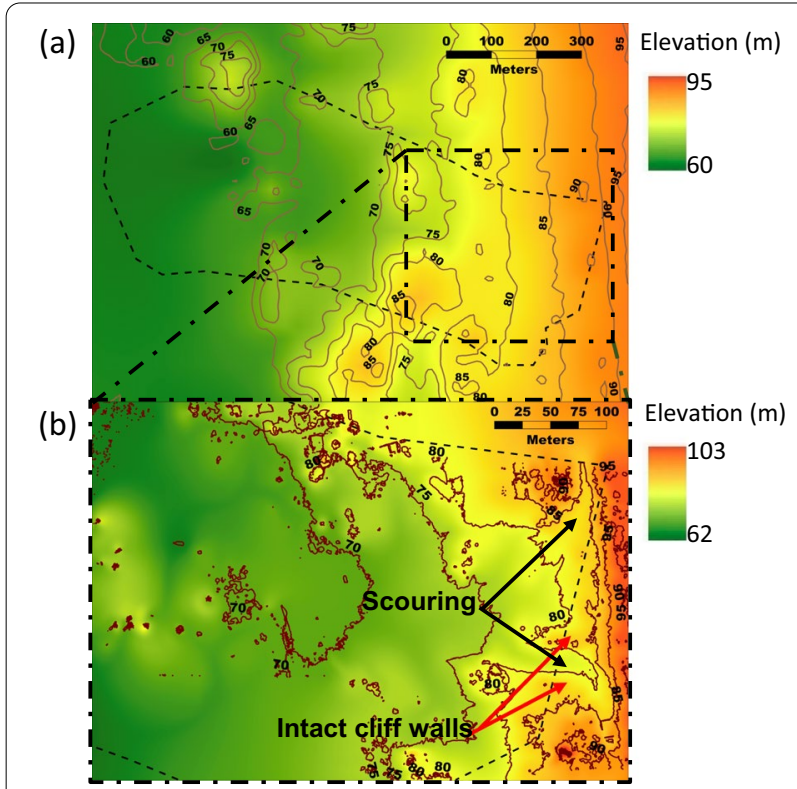

Fig. 16 Raster elevation profile of the Sibalaya flowslide site: a before earthquake (data source: BIG (2018)) and b after earthquake (surveyed on June 29, 2019)

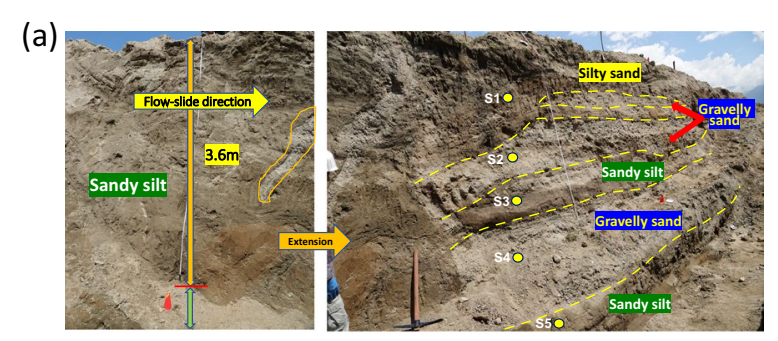

(b)

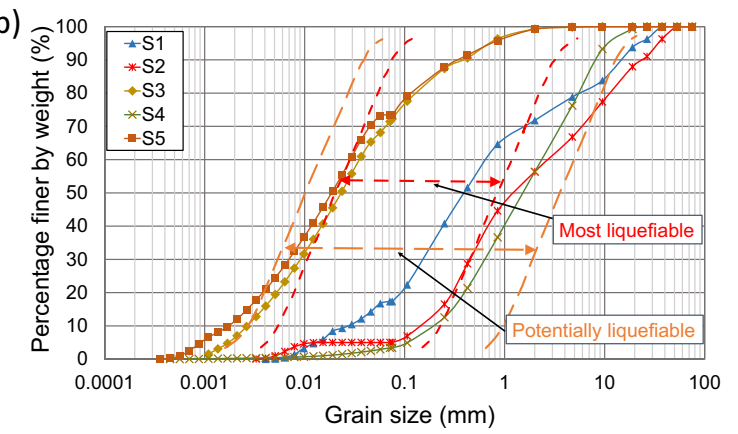

Fig. 17 Trench 1 in Sibalaya flowslide site: a soil lithology from the right wall with sampling locations for disturbed soil samples S1-S5 (images shot on June 28,2019 ) and $\mathbf{b}$ grain size distribution of the samples S1-S5

in the fields behind the Trench 4, with a ground elevation $6 \mathrm{~m}$ above the location of PDCPT 2. The location of this PDCPT 3 is shown in Fig. 15, and the profile of $\mathrm{N}$ value versus depth is shown in Fig. 20c. The overall soil profile
Table 3 Fines content for samples S1-S5 from Trench 1 in Sibalaya

\begin{tabular}{lccccc}
\hline & S1 & S2 & S3 & S4 & S5 \\
\hline Gravel $(>2 \mathrm{~mm})$ & 28.2 & 43.6 & 0.8 & 43.7 & 0.8 \\
Sand $(2 \mathrm{~mm}-75 \mu \mathrm{m})$ & 61.5 & 61.8 & 27.6 & 72.8 & 26.4 \\
Silt $(75 \mu \mathrm{m}-5 \mu \mathrm{m})$ & 17.3 & 4.0 & 52.8 & 3.0 & 49.0 \\
Clay $(<5 \mu \mathrm{m})$ & 0.1 & 1.0 & 19.4 & 0.5 & 24.4 \\
$C_{u}$ & 25.0 & 11.33 & 13.46 & 11.50 & 16.57 \\
$C_{c}$ & 1.33 & 0.79 & 0.89 & 0.86 & 0.97 \\
Fines content (\%) & 17.4 & 5.0 & 72.2 & 3.4 & 73.4 \\
\hline
\end{tabular}

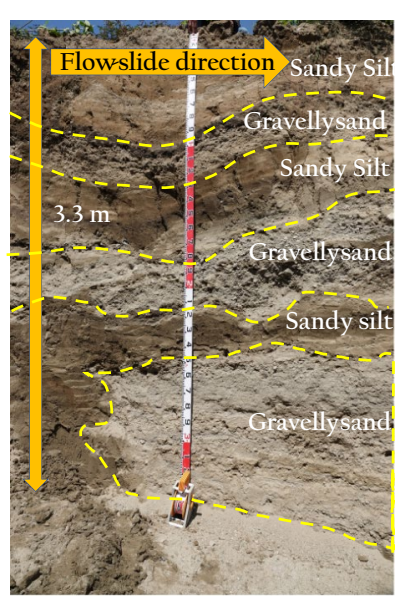

Fig. 18 Soil lithology from the right wall of Trench 2 (image shot on June 28, 2019) (a)

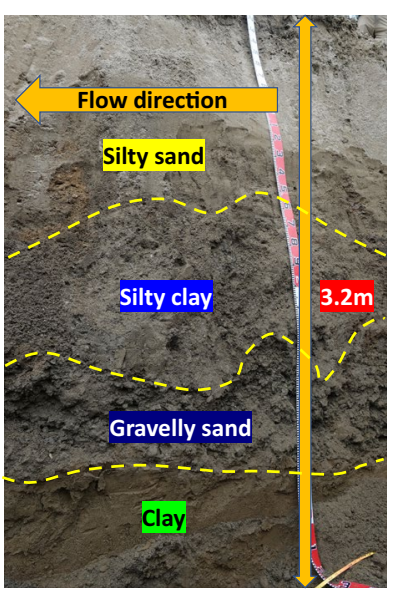

(b)

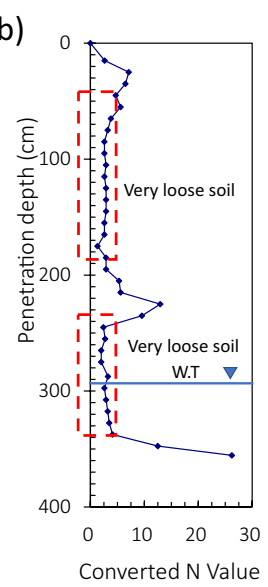

Fig. 19 Trench 3: a Soil lithology from the left wall of Trench 3 (images taken on June 30,2019 ) and $\mathbf{b} \mathrm{N}_{\text {SPT }}$ versus depth values for PDCPT 1 
(a)

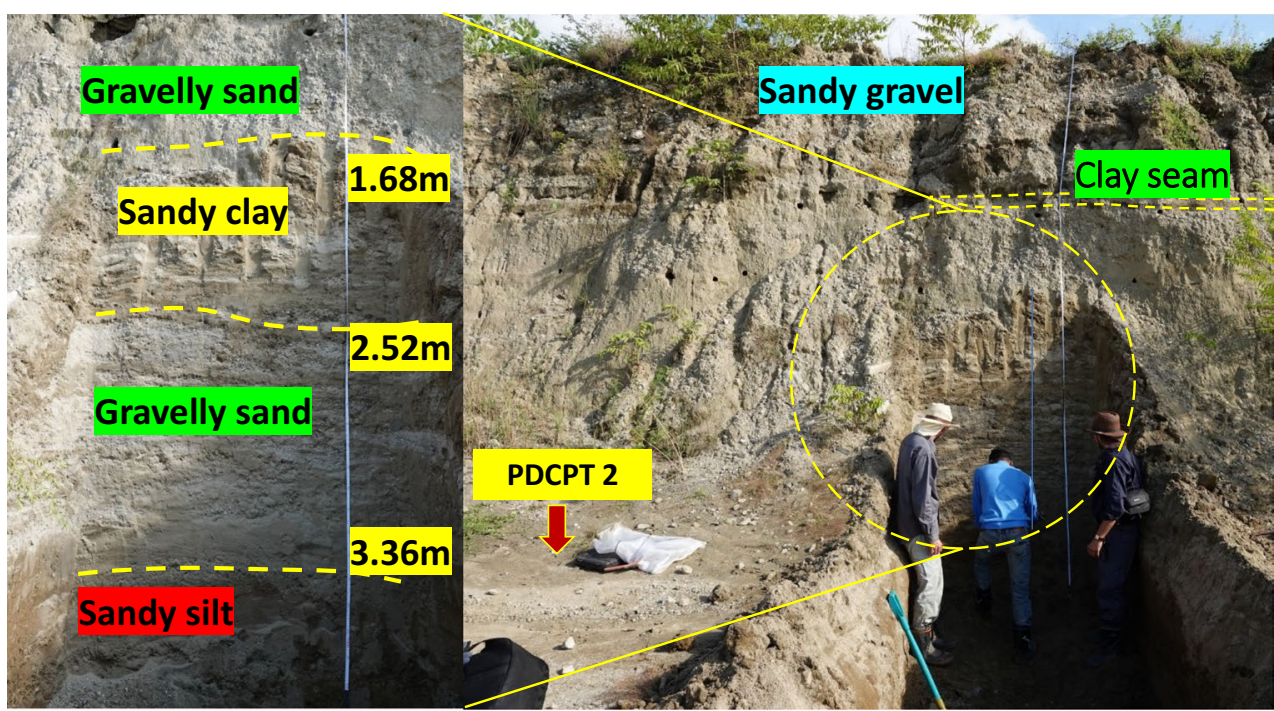

(b)

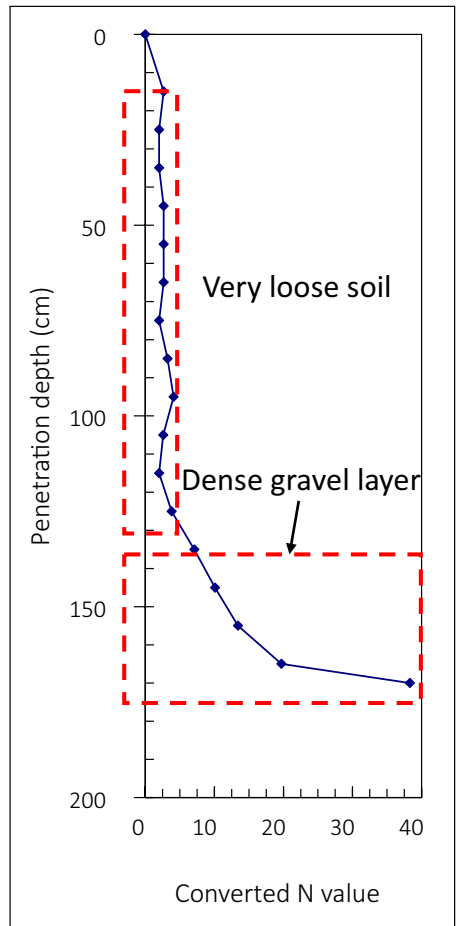

(c)

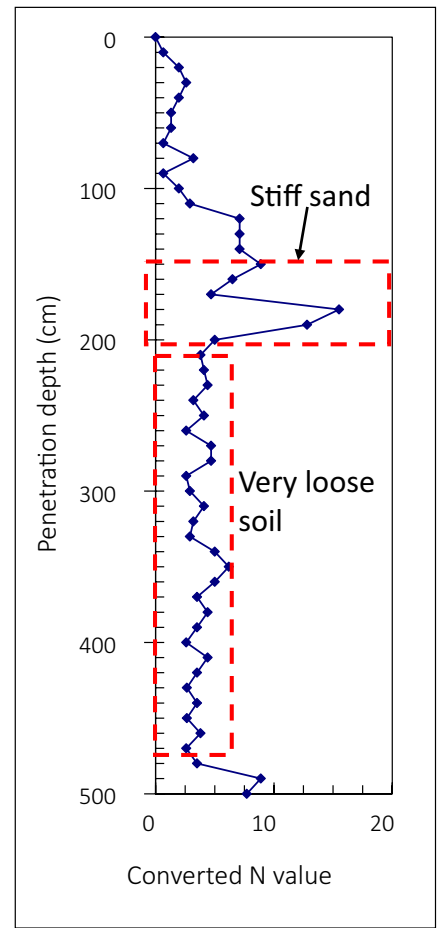

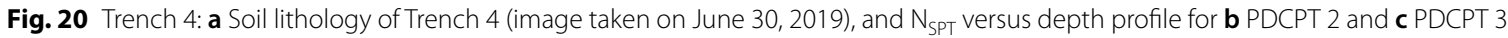

up to the sounding depth can be confirmed as very loose soil with a little resistance observed at $2 \mathrm{~m}$ depth.

Trench 5 is located on the opposite side of Trench 4 (Fig. 21). The opposite wall of Trench 5 has thin seams of fine silt at near the surface before the failure. The soil stratification of this trench is mainly composed of gravelly and sandy soil with the presence of several sandy gravel layers between sandy clay layers. The topsoil at this trench consists mainly of gravelly soil, with cobbles and stones. In addition, the holes seen on the wall of the trench are the nests of the rainbow bee-eater bird, which typically builds its nests in loose, gravelly, and sandy soil. This also confirms the looseness of the soil layers at this site. Although the vertical walls of Trenches 4 and 5 did not fail during the flowslides due to the predominance of gravelly sand at shallow depths, they may have softened 


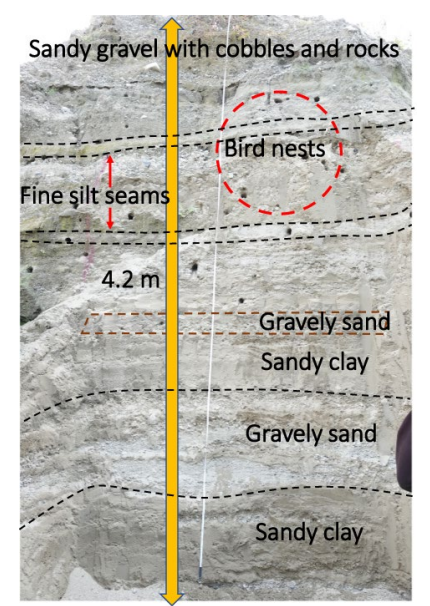

Fig. 21 Trench 5: Soil lithology of Trench 5 with stratified interlayer seams (image taken on June 29, 2019)

after being exposed to rain following the flowslide, allowing the birds to dig in the loose gravelly soil.

\subsection{Postulated mechanism}

The Petobo, Jono Oge, and Sibalaya sites were identical in the presence of agricultural fields, while the Balaroa site was an urban site with high-density residential structures. In addition, except for Balaroa, all other three sites had a canal full of water running through the head scarp, making it complicated and difficult to generalize a failure mechanism for all of them.

One of the key factors that influenced the cause of failure may be the proximity of the sites to the Palu Koro fault (PKF). Previous studies (Watkinson and Hall 2017) have reported that the PKF system is not a fully strikeslip fault, but experiences trans-tensional shear as it emerges from the tapered Palu Valley near Pakuli village. It consists of a basin-wide strike-slip fault and two sidewall faults that are mainly extensional sections of the main system, indicating a comparatively low tectonic rate. Therefore, most of the strike-slip strain in the Palu Valley is believed to be accumulated by the basin spanning fault system. This basin-wide fault is overlain by fluvial sediments deposited by the Palu River (Bellier et al. 2001). In addition, the locations of the flowslides were where these fluvial sediments converge with the alluvium fan deposits from the hills. The coastal and fluvial deposits are susceptible to liquefaction-induced flow failures. Many historic liquefaction-induced flow failures have been observed in the past in coastal and fluvial deposits (Kramer 1988; Field et al. 1982).

Furthermore, as observed from the trenches and vertical soil profiles, there appeared to be an abrupt change in vertical soil permeability from gravelly sand to sandy

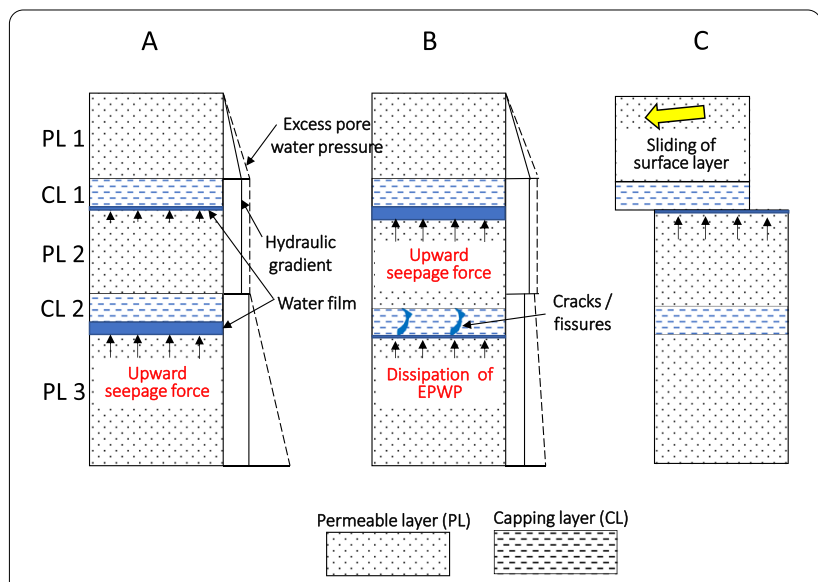

Fig. 22 Postulated mechanism of failure: $\mathbf{A}, \mathbf{B}$ and $\mathbf{C}$ are the stages of water film formation and consolidation of soil layers leading to flowslide

silt or clay layers. Kokusho (1999) demonstrated that such low permeable cap layers can lead to the formation of water film and cause a reduction in shear resistance against lateral sliding. Also, from the eyewitness accounts and previous studies conducted, there was no co-seismic triggering of the flowslides, which makes it to be a probable cause of progressive liquefaction layer by layer (Gallant et al. 2020). Therefore, it could be assumed that the soil layers liquefied layer by layer due to the drastic change in soil permeability in each layer with distinctive soil stratification. The liquefied soil layers could not dissipate excess pore water pressure in time due to the presence of capping layers above, thereby maintaining instability in the soil strata for a longer duration of time (Kokusho and Kojima 2002). In addition, water film formation and its influence on the lateral mass movement of the soil in a submarine environment were demonstrated by physical experiments in Kawakita et al. (2020).

A postulated failure mechanism based on the soil stratification observed at the sites is shown in Fig. 22 in three stages $(\mathrm{A}-\mathrm{C})$. The soil layers as observed in the field are divided into five layers for simplicity. Two very low permeability layers or the capping layers (CL) with a permeability coefficient, $k_{c}$, are wedged in between the permeable layers $(\mathrm{PL})$ with a permeability coefficient, $k_{\mathrm{p}}$, at different elevations. Assuming that the soil layers are fully saturated, the hydraulic gradient in CL is equal to $i_{\mathrm{c}}$ and in PL is equal to $i_{\mathrm{p}}$. As CL has much lower permeability as compared to PL in the order of two or more $\left(k_{\mathrm{p}}>>k_{\mathrm{c}}\right)$, therefore by the virtue of Darcy's law the $i_{\mathrm{p}}<<i_{\mathrm{c}}$. During liquefaction in stratified layers, the permeability $(k)$ and the hydraulic gradient $(i)$ are key parameters that control the flow of fluids and the dissipation of the excess pore water pressure (EPWP) through 
the fine soil layers. These also affect the formation of sand boils and water film during liquefaction (Yang and Elgamal 2001; Kokusho and Kojima 2002; Brennan and Madabhushi 2005). The mechanism of flowslide concerning to the hydraulic gradient $(i)$ influenced by the permeability of capping layers $(k)$ is discussed in three stages as follows:

A. Here, in stage A, as soon as the soil liquefies in the underlying permeable layers, the excess pore water starts to migrate to the surface from higher pressure gradient to lower pressure gradient for dissipation. When the pore water in the PL3 encounters a low permeable cap layer CL2, it forms a water film beneath it; simultaneously, the pore water stored in PL2 also forms a water film below CL1, although it may not be as thick as the one below PL3 due to limited storage of pore water in PL2. Therefore, there will be a much lower hydraulic gradient at CL1 (ic1<ic2). The excess pore water pressure will be maximum below CL2 at this stage. During this stage, PL3 continues to settle as the water gets accumulated from the pores into the water film. Due to the high hydraulic head at CL2, an upward seepage force is generated on the CL2, which may then form fissures in CL2 at weak spots as it may not be able to lift it up due to overburden pressure from overlying layers. The excess pore water then dissipates to PL2, thereby letting the PL3 to settle. This excess pore water collected in PL2 then increases the hydraulic head at CL1. As the water film diffuses from PL3, the excess pore pressure also dissipates, leading to the settlement of this layer. At this stage, the excess pore water pressure is assumed to be maximum at PL2.

B. The hydraulic head generated at CL1 due to accumulation of all the excess pore water below the CL1 as water film may now overcome the buoyant unit weight of already softened and disturbed surface layer (PL1), thereby lifting and destabilizing it and initiating a flowslide.

The mechanism of water film formation in terms of hydraulic gradient and permeability has been explained in detail in Kokusho and Kojima (2002) for a single capping layer, while this may become a more complex mechanism in the presence of multiple capping layers. However, for the flowslide to occur over a large area due to the formation of water film, the cap layers need to be continuous across the whole area or a major part of the area; this is yet to be ascertained and needs further field investigation. Additionally, an alternate hypothesis has also been proposed which assumes that, due to the probable liquefaction of surface layer during the earthquake, the frictional resistance against the lateral movement might have reduced drastically; this initiated a major landslide along the slope under the influence of gravity. As the surface was ruptured due to the triggering of landslide, the water from the underlying confined aquifer might have rushed to the surface supplying additional water to the already liquified layer, thereby sustaining the flow for a long distance and time (JICA 2019).

\section{Conclusions}

This paper provides an insight into the outcomes of the forensic geotechnical survey conducted aftermath of the 2018 Sulawesi earthquake. Significant destruction due to the earthquake was caused due to the extensive flowslides in Balaroa, Petobo, Jono Oge, and Sibalaya areas of Palu Valley. The authors have presented the findings of the field investigations from all the locations with an emphasis on the Sibalaya site. Trench surveys and in situ tests significantly helped in the identification and classification of liquefiable deposits. Based on the information accumulated in this research, the following conclusions could be made:

- The presence of liquefiable deposit along with the presence of multiple capping layers might have contributed to triggering the flowslides.

- The properties and particle size of the cap layers vary across the site as observed from trench survey. In addition, the presence of notable amount of clay content in silt layers in Sibalaya trench may have significantly delayed the dissipation of excess pore water pressure from the underlying sand layers, thereby leading to the formation of water film below the low permeability cap layers.

- In Sibalaya, most of the upstream damage seems to have caused by erosion due to the flood originating from the ruptured canal; this also seems to have contributed to the damage by the flowslide.

- The width of the flowslide is limited to the locations of the canal rupture, and the sliding has not spread in the lateral direction; therefore, water seepage from the unlined irrigation canal may not have significant contribution in the triggering of flowslides.

- The shallow geology, along with proximity to the Palu-Koro Fault may also be considered a contributing factor causing site amplification. Furthermore, each site has its own dominating factor for triggering the flowslide; therefore, a site-specific hazard analysis is recommended for each site, with spatial soil profiling.

- The current study only focuses on the triggering of the flowslides; however, the factors which contributed to the long duration and the extent of the 
flowslides also need to be studied, which is a topic of future research.

\begin{abstract}
Abbreviations
BIG: Badan Informasi Geospasial/Geospatial Information Agency of Indonesia; $\mathrm{CL}$ : Capping layer; $\mathrm{C}_{\mathrm{c}}$ : Coefficient of curvature; $\mathrm{C}_{\mathrm{u}}$ : Coefficient of uniformity; DEMNAS: National Bathymetry Seamless Digital Elevation Model; ECS: Eastern Central Sulawesi; EPWP: Excess pore water pressure; GCMD: Global Change Master Directory; GCMT: Global Centroid Moment Tensor; $i_{c}$ : Hydraulic gradient in capping layer; $i_{p}$ : Hydraulic gradient in permeable layer; $k_{c}$ : Coefficient of permeability of capping layer; $k_{p}$ : Coefficient of permeability of permeable layer; MMl: Modified Mercalli intensity; $M_{\mathrm{b}}$ : Body wave magnitude; $M_{s}$ : Surface wave magnitude; $M_{w}$ : Moment magnitude; NDVl: Normalized Differential Vegetation Index; $N_{d}$ : PDCPT $N$ values; $N_{\text {SPT: }}$ PDCPT $N$ values converted to standard penetration tests $N$ values; PDCPT: Portable dynamic cone penetration testing; PHRI: Port and Harbor Research Institute; PKF: Palu-Koro Fault; PGA: Peak ground acceleration; PL: Permeable layer; USGS: United States Geological Survey.
\end{abstract}

\section{Acknowledgements}

The authors would like to express their sincere gratitude to the members of the JICA domestic committee for technical support to the 2018 Sulawesi Earthquake, Indonesia. Particular thanks are extended to Prof. Kenji Ishihara, Prof. Susumu Yasuda, Prof. IkuoTowhata, Prof. Masyhur Irsyam, Prof. Mitsu Okamura, Dr. Takashi Kiyota, Dr. Kimio Takeya and Dr. Ardy Arsyad for their valuable support and suggestions. We are also grateful to the students of Tadulako University, Palu, for their help and support during the field investigations. And last but not the least, the authors would like to thank the Exprodat Team for providing them the trial access to their Data Assistant software (http://www. exprodat.com/) as well as Agisoft Metashape (https://cloud.agisoft.com/) for providing access to their cloud computing service.

\section{Authors' contributions}

DR conceived, investigated, and wrote the manuscript. $\mathrm{HH}$ is the principle investigator of the project and performed planning and supervision. TM done laboratory analysis of samples. WOS contributed to site investigation and logistic support. TK contributed to inputs in conceptualization, discussions, and suggestions. SMKP helped in suggestions during the second revision. SN provided site investigation and logistic support. All authors read and approved the final manuscript.

\section{Funding}

The authors would like to acknowledge the financial support for this research under JSPS (Japan Society for Promotion of Science) KAKENHI (Grant Number 20H02244; Principal Investigator: Hemanta Hazarika).

\section{Availability of data and materials}

The sources and Web sites used for the data have been duly cited in the manuscript and available in the References section. The images used are taken by our team members.

\section{Declarations}

\section{Competing interests}

The authors declare that there are no competing interests with the data published in this research.

\section{Author details}

${ }^{1}$ Kyushu University, Nishi-ku, Fukuoka 819-0395, Japan. ${ }^{2}$ Chuo University, Hachioji, Tokyo 192-0393, Japan. ${ }^{3}$ IMAGEi Consultant Corporation, Chiyoda-ku, Tokyo 102-0083, Japan. ${ }^{4}$ Tadulako University, Palu, Central Sulawesi 94118 , Indonesia.
}

Received: 25 April 2021 Accepted: 9 October 2021 Published online: 28 October 2021

\section{References}

Bellier O, Siame L, Beaudouin T, Villeneuve M, Braucher R (2001) High slip rate for a low seismicity along the Palu-Koro active fault in Central Sulawesi (Indonesia). Terra Nova 13(6):463-470

Bellier O, Sébrier M, Seward D, Beaudouin T, Villeneuve M, Putranto E (2006) Fission track and fault kinematics analyses for new insight into the Late Cenozoic tectonic regime changes in West-Central Sulawesi (Indonesia). Tectonophysics 413(3-4):201-220

Fang J, Xu C, Wen Y, Wang S, Xu G, Zhao Y, Yi L (2019) The 2018 Mw 7.5 Palu earthquake: a supershear rupture event constrained by InSAR and broadband regional seismograms. Remote Sens 11(11):1-15

Field ME, Gardner JV, Jennings AE, Edwards BD (1982) Earthquake-induced sediment failures on a 0.25 o slope, Klamath River delta, California. Geology 10(10):542-546

Gallant AP, Montgomery J, Mason HB, Hutabarat D, Reed AN, Wartman J, Irsyam M, Simatupang PT, Alatas IM, Prakoso WA, Djarwadi D, Hanifa R, Rahardjo P, Faizal L, Harnanto DS, Kawanda A, Himawan A, Yasin W (2020) The Sibalaya flowslide initiated by the 28 September 2018 MW 7.5 PaluDonggala, Indonesia earthquake. Landslides 17(8):1925-1934

Geospatial Information Agency of Indonesia (BIG) (2018) National bathymetry seamless digital elevation model. http://tides.big.go.id/DEMNAS/. Accessed 1 Jan 2021

Global Change Master Directory (GCMD) (2020) GCMD Keywords, Version 9.1.5. Greenbelt, 473 MD: Earth Science Data and Information System, Earth Science Projects Division, 474 Goddard Space Flight Center (GSFC) National Aeronautics and Space Administration 475 (NASA). https://earth data.nasa.gov/gcmd-forum

Hall R (2014) Indonesian tectonics: subduction, extension, provenance and more. In: Ndonesian Petroleum Association, Proceedings of the 38th annual convention, IPA14-G-360, August, 1-43

Hamilton WB (1979) Tectonics of the Indonesian region (Issue 1078). U.S. Government Publishing Office, Washington, DC

Hazarika H, Rohit D, Kiyota T, Okamura M, Pasha SMK, Nurdin S (2021a) Forensic evaluation of long-distance flow in gently sloped qround during the 2018 Sulawesi Earthquake Indonesia. In: Sitharam TG, Jakka RS, Kolathayar $S$ (eds) Latest developments in geotechnical earthquake engineering and soil dynamics. Springer, Singapore, pp 247-280

Hazarika H, Rohit D, Pasha SMK, Maeda T, Masyhur I, Arsyad A, Nurdin S (2021 b) Large distance flow-slide at Jono-Oge due to the 2018 Sulawesi Earthquake, Indonesia. Soils Found 61(1):239-255

Hungr O, Leroueil S, Picarelli L (2014) The Varnes classification of landslide types, an update. Landslides 11(2):167-194

Japan International Cooperation Agency (JICA) (2019) Report of the technical committee on The 2018 Sulawesi earthquake, Indonesia

Kawakita S, Asahina D, Takemura T, Hosono H, Kitajima K (2020) Effect of hydraulic and mechanical characteristics of sediment layers on water film formation in submarine landslides. Prog Earth Planet Sci 7(1):1-12

Kiyota T, Furuichi H, Hidayat RF, Tada N, Nawir H (2020) Overview of longdistance flow-slide caused by the 2018 Sulawesi earthquake, Indonesia. Soils Found 60(3):722-735

Kokusho T (1999) Water film in liquefied sand and its effect on lateral spread. J Geotech Geoenviron Eng 125(10):817-826

Kokusho T, Kojima T (2002) Mechanism for postliquefaction water film generation in layered sand. J Geotech Geoenviron Eng 128(2):129-137

Kramer SL (1988) Triggering of liquefaction flow slides in coastal soil deposits. Eng Geol 26(1):17-31

Kusumawardani R, Chang M, Upomo TC, Huang R, Fansuri MH, Prayitno GA (2021) Understanding of Petobo liquefaction flowslide based on site reconnaissance. Landslides. https://doi.org/10.1007/s10346-021-01700-x

Mason B, Hutabarat D, Prakoso W (2019) Geotechnical reconnaissance: The 28 September 2018 M7.5 Palu-Donggala, Indonesia Earthquake PacTrans-SSI Bridge Project View project Aceh-Pidie Mw 6.5 Earthquake Aftershock 2016 Monitoring View project. Report of Geotechnical Extreme Events Reconnaissance, The Geotechnical Extreme Events Reconnaissance (GEER) Association, April, 1-86. https://doi.org/10.18118/G63376

Metallic Minerals Exploration Agency (1973) Report on Geological Survey of Central Sulawesi, Indonesia.pdf

National Agency of Disaster Management (BNPB), Gempa Bumi Sulteng (2020) Retrieved January 15, 2021, from https://bnpb.go.id/geoportal.html 
Okamura M, Ono K, Arsyad A, Minaka US, Nurdin S (2020) Large-scale flowslide in Sibalaya caused by the 2018 Sulawesi earthquake. Soils Found 60(4):1050-1063

Patria A, Putra PS (2020) Development of the Palu-Koro Fault in NW Palu Valley, Indonesia. Geosci Lett 7(1):1-11

Simandjuntak TO, Supandjono BJ (1991) Geologic map and report of the Poso quadrangle, South Sulawesi, scale 1:250,000

Socquet A, Simons W, Vigny C, McCaffrey R, Subarya C, Sarsito D, Ambrosius B, Spakman W (2006) Microblock rotations and fault coupling in SE Asia triple junction (Sulawesi, Indonesia) from GPS and earthquake slip vector data. J Geophys Res Solid Earth 111(8):1-15

Surono and Sukarna D (1996) Sedimentology of the Sulawesi molasse in relation to Neogene tectonics, Kendari area, eastern Indonesia. In: Proceedings of the 6th international congress of Pacific Neogene Stratigraphy and IGCP355, pp 57-72

USGS (2018) United States Geological Survey. https://www.usgs.gov/

Van Leeuwen T, Allen CM, Kadarusman A, Elburg M, Palin JM (2007) Petrologic, isotopic, and radiometric age constraints on the origin and tectonic history of the Malino Metamorphic Complex, NW Sulawesi, Indonesia. J Asian Earth Sci 29(5-6):751-777

van LeeuwenMuhardjo TM (2005) Stratigraphy and tectonic setting of the Cretaceous and Paleogene volcanic-sedimentary successions in northwest
Sulawesi, Indonesia: implications for the Cenozoic evolution of Western and Northern Sulawesi. J Asian Earth Sci 25(3):481-511

van Leeuwen T, Allen CM, Elburg M, Massonne HJ, Palin JM, Hennig J (2016) The Palu Metamorphic Complex, NW Sulawesi, Indonesia: origin and evolution of a young metamorphic terrane with links to Gondwana and Sundaland. J Asian Earth Sci 115:133-152

Watkinson IM, Hall R (2017) Fault systems of the eastern Indonesian triple junction: evaluation of quaternary activity and implications for seismic hazards. Geol Soc Spec Publ 441(1):71-120

Yang Z, Elgamal A (2001) Sand boils and liquefaction--induced lateral deformation. In: 15th International conference on soil mechanics and geotechnical engineering, 1989, pp 345-350

Zhang Z, Xu J, Huang H, Chen X (2017) Seismic characteristics of supershear and sub-Rayleigh earthquakes: Implication from simple cases. Geophys Res Lett 44(13):6712-6717

\section{Publisher's Note}

Springer Nature remains neutral with regard to jurisdictional claims in published maps and institutional affiliations.

\section{Submit your manuscript to a SpringerOpen ${ }^{\circ}$ journal and benefit from:}

- Convenient online submission

- Rigorous peer review

- Open access: articles freely available online

- High visibility within the field

Retaining the copyright to your article

Submit your next manuscript at $\boldsymbol{\nabla}$ springeropen.com 